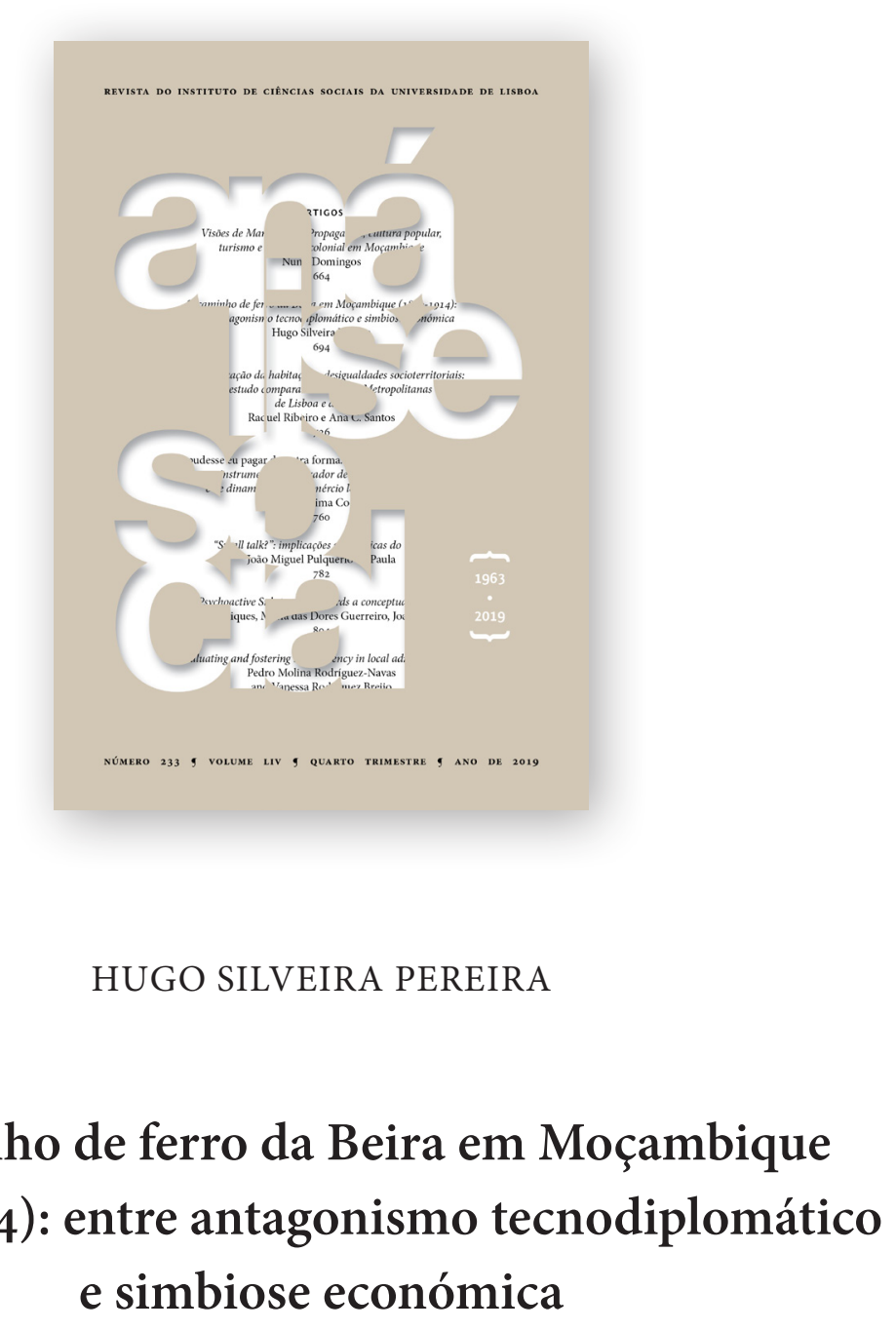

\title{
O caminho de ferro da Beira em Moçambique (1890-1914): entre antagonismo tecnodiplomático e simbiose económica
}

\author{
Análise Social, LIV $\left(4 .^{\circ}\right), 2019\left(\right.$ n. $\left.^{\circ} 233\right)$, pp. 694-724 \\ https://doi.org/10.31447/ASO0032573.2019233.02 \\ ISSN ONLINE 2182-2999
}


Análise Social, 233, LIV $\left(4 .^{\circ}\right), 2019,694-724$

O caminho de ferro da Beira em Moçambique (1890-1914): entre antagonismo tecnodiplomático e simbiose económica. Em 1892, como consequência de um tratado assinado entre Portugal e a Inglaterra, uma companhia britânica controlada por Cecil Rhodes e pela sua BSAC iniciou a construção de uma ferrovia entre o porto moçambicano da Beira e a fronteira rodesiana. Apesar dos receios de desnacionalização dos territórios portugueses, a construção e operação foram conduzidas praticamente sem fiscalização das autoridades nacionais. A linha nada custou ao tesouro português e a sua operação transfronteiriça tornou-se bastante eficiente. Neste artigo pretendo explicar este processo histórico à luz dos conceitos de grandes sistemas tecnológicos transnacionais, cross-borders, landlocked countries e tecnodiplomacia.

PALAVRAS-CHAVE: imperialismo ferroviário; partilha de Africa; companhias majestáticas; bitola estreita.

The Beira railway in Mozambique (1890-1914): between technodiplomatic antagonism and economic symbiosis. Because of a treaty signed between Portugal and England, in 1892 a British Company controlled by Cecil Rhodes' BSAC began the construction of a railway between the Mozambican harbor of Beira and the Rhodesian frontier. Despite the fears of denationalization of the Portuguese territories, construction and operation were conducted almost without any inspection from Portuguese authorities. The line cost Portugal nothing and its cross-border operation became rather efficient. In this paper, I aim to explain this historical process, using the concepts of large transnational technological systems, cross-borders, landlocked countries, and technodiplomacy.

KEYWORDS: railway imperialism; scramble for Africa; chartered companies; narrow gauge.

https://doi.org/10.31447/Asooo32573.2019233.02 


\section{O caminho de ferro da Beira em Moçambique (1890-1914): entre antagonismo tecnodiplomático e simbiose económica}

\section{INTRODUÇÃO}

Em 1891, na sequência do Ultimato Inglês de 1890, foi autorizada a construção em Moçambique de um caminho de ferro da Beira, através dos territórios de Manica e de Sofala, até à fronteira com a esfera de influência britânica. Apesar do valor conferido à região, da sabida cobiça inglesa sobre a mesma e do conhecido potencial da ferrovia como instrumento de imperialismo e desnacionalização de territórios, a linha foi adjudicada a um grupo de investidores ingleses, que, nas décadas seguintes, geriram a construção e operação quase sem fiscalização das autoridades portuguesas.

Estes acontecimentos foram tratados pela primeira vez por Lima (1971, vol. 2, pp. 97-140), que deles fornece um detalhadíssimo relato, ainda que de forma eminentemente descritiva. Mais recentemente, os trabalhos de Teixeira (1991, pp. 71-77), Direito (2013) e Navarro (2018, pp. 382-401) analisaram este processo histórico recorrendo a instrumentos e metodologias da historiografia académica, evidenciando a crescente presença estrangeira na infraestrutura e no território (e consequente desnacionalização do mesmo). Considerando o forte envolvimento britânico no processo, não é de estranhar que autores anglo-saxónicos tenham também analisado o tema, favorecendo representações britânicas (Baxter, 1998; Croxton, 1982).

Neste artigo, adiciono novos dados sobre a construção e sobretudo sobre a operação da linha da Beira (até ao deflagrar da Primeira Guerra Mundial, que iniciou um novo modelo de exploração ferroviária), inserindo-as no contexto geopolítico sul-africano, na estrutura empresarial criada por Cecil Rhodes e no âmbito da evolução do sistema ferroviário colonial/metropolitano nacional, 
recorrendo a conceitos usados no debate académico internacional sobre grandes sistemas tecnológicos transnacionais/cross-borders, landlocked countries e tecnodiplomacia. Complemento e aprofundo, assim, um trabalho que desenvolvi anteriormente sobre o assunto (Pereira, 2017a, pp. 240-250), ilustrando como a linha, apesar de ter nascido de uma imposição (tecno)diplomática e de ter promovido a fixação de elementos estrangeiros no território (indesejada pelos colonialistas nacionais), acabou por contribuir para a colonização e para a dinamização económica e comercial das regiões sob domínio inglês e português.

O primeiro daqueles conceitos refere-se a "human-made, materially integrated structures that cross national boundaries" (Vleuten e Kaisjer, 2006, p. 6), como era o caso da linha da Beira, que atravessava a fronteira entre Manica e a Rodésia, atual Zimbabwe (Mapa 1). Nestas infraestruturas cross-borders, a fronteira pode ser um obstáculo ponderoso, que impede o usufruto pleno daqueles sistemas técnicos (López et al., 2009, pp. 47-48).

Este problema é particularmente grave para territórios completamente rodeados por terra (landlocked countries), que estavam dependentes dos países vizinhos para acederem ao mar. Neste artigo, a Rodésia assume o papel de landlocked country, cujo porto mais próximo (Beira) ficava em território português. A alternativa era uma longa viagem até aos portos sul-africanos. Contudo, o país com acesso ao mar pode também estar dependente do vizinho encravado, se não possuir suficiente dinamismo económico e necessitar do tráfego das regiões adjacentes para justificar um caminho de ferro (Pereira, 2017b, pp. 176-177). Era o caso de Manica e Sofala, que, em teoria, beneficiariam mais do trânsito da Rodésia do que daquele gerado pelos seus próprios recursos.

Para que uma ligação transfronteiriça se efetue eficazmente e seja mais do que uma mera conexão com padrões técnicos semelhantes (Vleuten, 2006, pp. 286-290), é necessário estabelecer relações políticas pacíficas entre os países envolvidos e criar processos de through-traffic (Faye et al., 2004, pp. 40-43); em alternativa, forçar essa fluidez pela força militar (Divall, 2003, p. 196). Porém, este requisito pode ser dificultado pelas diferentes agendas tecnológicas das partes (Pereira, 2017b, p. 177), considerando que uma ferrovia é mais do que um mero meio de transporte e pode atuar como instrumento de imperialismo e apropriação territorial (Robinson, 1991, pp. 180-189), símbolo nacionalista e fomentador de identidades nacionais (Nye, 1999, pp. 47-48 e 68). No contexto analisado, uma linha férrea em Manica e Sofala seria um valioso trunfo de apropriação colonial e afirmação de soberania para a nação que o controlasse (além de fomentar a colonização das regiões atravessadas).

Para limar as diferenças entre agendas tecnológicas, é necessário encetar negociações internacionais (que se podem estender até à exploração dos 
MAPA 1

As ligações ferroviárias da Rodésia à Beira, ao Congo e à África do Sul ${ }^{1}$, c. 1910.

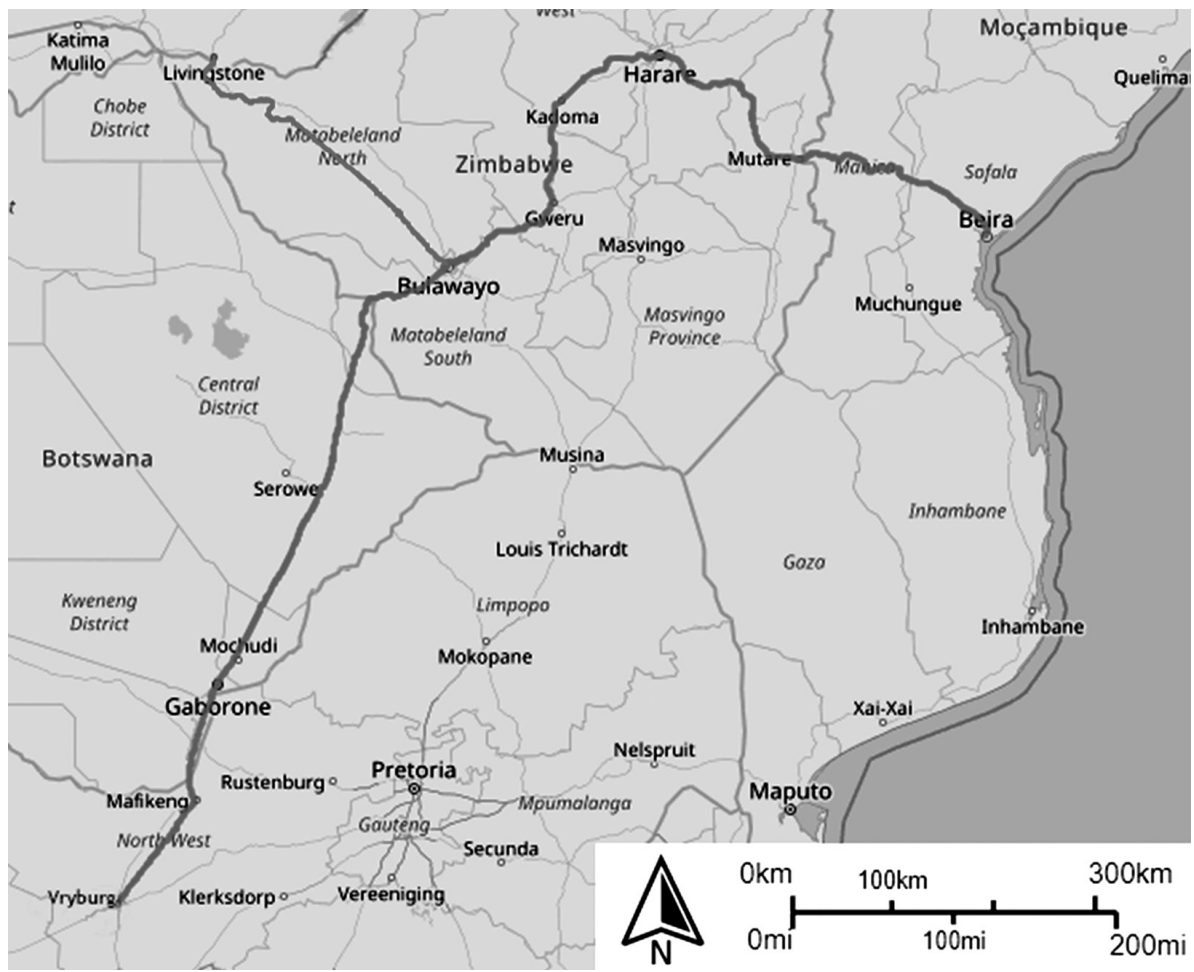

Fonte: sharemap.org e elaboração própria.

sistemas), em rondas que se podem apelidar de tecnodiplomacia, durante as quais agentes tecnodiplomáticos (governos, empreendedores que propõem os sistemas técnicos, engenheiros que os projetam e constroem e companhias que os financiam e operam) procuram usar a tecnologia em discussão para impor os seus próprios interesses (Pereira, 2017b, p. 177). Neste estudo, com uma disputa entre Portugal e Inglaterra sobre uma via-férrea entre a Beira e a Rodésia, no contexto de um tratado imposto na sequência de um ultimato, a tecnodiplomacia aplica-se perfeitamente.

Estes conceitos serão aplicados a um conjunto diversificado de fontes (relatórios, correspondência, debates parlamentares, estatísticas e fotografias) espalhado por vários arquivos portugueses e britânicos.

1 Usarei as expressões Rodésia e África do Sul por conveniência de linguagem e para me referir, respetivamente, ao território da BSAC e às colónias Boers (Transval e Orange) e inglesas (Cabo e Natal) e não à realidade geopolítica formada em 1910 pela fusão destes quatro territórios, nem à entidade independente que viriam a constituir em 1934. 


\section{CONTEXTO GEOPOLÍTICO}

Manica e Sofala eram mal conhecidas dos portugueses (Pery, 1875, p. 361). Trata-se de uma região permeada por montes com uma altitude de $1600-$ -2400 m (Vasconcelos, 1921, p. 424), com zonas luxuriantemente arborizadas, povoadas por animais ferozes (Moura, 1885), e outras infestadas pela mosca do sono, que dificultava a fixação de colonos (Alford, 1893 ). ${ }^{2} \mathrm{O}$ clima é quente (máximos de $42^{\circ}$ ), chuvoso (todo o ano, exceto junho e agosto) e húmido (até 77\%) (Vasconcelos, 1921, pp. 457-458). A Beira, em particular, ficava num "lodaçal [...] de cotas muito baixas e de contornos constantemente modificadas pelas marés" (Amaral, 1969, p. 76). Quanto ao potencial económico, falava-se em produções de trigo, tabaco, borracha, café, cana, âmbar e ouro (Machado, 1895, pp. 491-516; Pery, 1875, pp. 366-367). Os rios Búzi e Púnguè eram as únicas vias de penetração, embora o limite da sua navegabilidade não se afastasse muito da costa (Vasconcelos, 1921, pp. 433-436).

Portugal começou a marcar a sua presença na região desde 1878 , com a concessão Paiva de Andrada (Axelson, 1967, pp. 120-124). Na sequência da Conferência de Berlim, intensificaram-se ações militares e explorações geográficas em Manica (Alexandre e Dias, 1998, pp. 112-115 e 138-140) e, em 1887 , uma expedição portuguesa fundou na margem esquerda do Púnguè a vila da Beira (Amaral, 1969, p. 76).

Em 1888, Paiva de Andrada formou a CdM, à qual o governo concedeu direitos de exploração de um vasto território compreendendo Manica, Sofala e Beira. A empresa tinha sede em Portugal, mas era dominada por capital britânico, tendo um comité em Londres (Axelson, 1967, pp. 133-134). A cdM assumiu ainda a obrigação de construir uma ferrovia até Macequece, na fronteira com os territórios britânicos. ${ }^{3}$ Simultaneamente, surgiram outros alvitres para construir linhas férreas na região e ali afirmar a soberania nacional (Navarro, 2018, p. 384).

O expansionismo português desagradou a Inglaterra, que entregou à BSAC, fundada por Cecil Rhodes em 1889, a Mashonalândia, uma zona vizinha de Manica, que Portugal também reclamava para $\mathrm{si}^{4}{ }^{4} \mathrm{O}$ diferendo escalou até que Londres lançou um ultimato a Lisboa, exigindo a retirada das forças portuguesas do Chire e da Mashonalândia (Alexandre, 2008, pp. 115-119 e 171-175).

2 The Railway Magazine, 4, 1900, pp. 427-437.

3 LEGIS, 1, 385-388. COLP (1891, p. 810).

4 Mais tarde, Rhodes adicionou a Bechuanalândia (atual Botsuana), a Barotzelândia (parte da Zâmbia) e a Matabelelândia (parte do Zimbabué) à sua concessão (Pakenham, 2003, pp. 381$-387)$. 


\section{A CONCESSÃO VAN LAUN E A CONSTRUÇÃO DA LINHA}

Os acontecimentos que desembocaram na adjudicação e assentamento do caminho de ferro da Beira encontram-se bem descritos nos trabalhos referidos anteriormente (Baxter, 1998, pp. 1-5; Croxton, 1982, pp. 15-18; Lima, 1971, vol. 2, pp. 97-116; Navarro, 2018, pp. 386-391; Teixeira, 1991, pp. 74-76). Nesta secção, que serve de contextualização para as secções seguintes, seguirei, grosso modo, as narrativas destes autores, analisando-as dentro dos conceitos que indiquei e acrescentando, sempre que necessário, informação complementar.

Após o Ultimato, a Cdm procedeu de imediato à realização de estudos para a construção de uma ferrovia, de modo a afastar quaisquer pretensões estrangeiras sobre o território. Diversos empreendedores estrangeiros apresentaram também ofertas, invocando a importância (tecnodiplomática) da linha. Todavia, a Direção-Geral do Ultramar ponderou que a entrada de capital estrangeiro em Moçambique podia contribuir para a sua desnacionalização $0^{5}$, tal como se temia que acontecesse noutros empreendimentos ferroviários no Império: linhas de Mormugão, Ambaca e Lourenço Marques (Pereira, 2015, pp. 251-261; Navarro, 2018, pp. 283-293; Telo, 1991, 84-166).

Em 11 de junho de 1891, Portugal e Inglaterra terminavam o conflito com a assinatura de um tratado que definia os limites das respetivas áreas de influência em Moçambique e obrigava o governo português a melhorar o porto da Beira e a construir um caminho de ferro desde a baía do Púnguè até à fronteira. Estabelecia-se assim o acordo para assegurar a construção da ligação transfronteiriça, ainda que resultasse de uma imposição diplomática, que prometia dificultar o acerto de acordos de through-traffic. Para complicar o processo, o governo português não escondia o desejo de controlar a linha (Vilhena, 1916, vol. 1, p. 240), enquanto a BSAC pretendia o domínio da via-férrea não só para garantir um tráfego cross-border fluido até um porto no Índico, mas também visando a apropriação de Manica e Sofala (Lunn, 1997, p. 19).

Em Moçambique, agentes tecnodiplomáticos continuaram a disputa. A cdm procurou dar início à construção para afastar qualquer pretensão dos britânicos sobre a via-férrea, mas acabou por adjudicá-la a Theodore van Laun, um sócio de Rhodes (Lunn, 1997, pp. 19-20). Em Portugal, não tardaram os paralelismos com a questão da linha de Lourenço Marques. No parlamento, Ferreira de Almeida cotejava:

5 AHU, maço 491 1F, requerimento de 9-5-1891 e parecer de 31-6-1891; maço 2670 1B, requerimento de 5-12-1890 e parecer de 18-12-1890. 
O contrato do caminho de ferro de Lourenço Marques [...] tem um perfeito parallelo com o caminho de ferro do Pungue; a empreza adjudicou a construcção d’aquelle caminho de ferro a um empreiteiro, Mac-Murdo, a companhia de Moçambique adjudica tambem a construcção a um empreiteiro, Van Laun! ${ }^{6}$

Van Laun agiu como testa de ferro e agente tecnodiplomático de Rhodes e vendeu a concessão à BeiraCo, uma sociedade fundada em Londres em 12 de julho de 1892. Não era uma companhia por ações, o que surpreendeu o Board of Trade inglês, que não entendia como podia uma empresa ferroviária angariar capital sem emitir ações. ${ }^{7}$ Ao invés, foram emitidos 600 mil títulos sem valor nominal, pelos quais se fazia a distribuição de votos e de lucros. A BSAC subscreveu 305 mil e os membros do comité de Londres da cdm o restante, o que dava pleno controlo aos interesses britânicos. ${ }^{8}$ A companhia estava ainda autorizada a emitir até 250 mil libras em obrigações (sob hipoteca de $250 \mathrm{mil}$ títulos da BSAC), que constituíram a sua única fonte de financiamento. ${ }^{9}$

A construção foi assegurada por agentes ingleses, o que reforçou a predominância britânica no sistema tecnológico. Tratava-se dos empreiteiros Lawley e Pauling, com vasta experiência de construção em África (Pauling, 1969, p. 22), os quais constituíram para o efeito a empresa L\&P. $O$ engenheiro Mansergh $^{10}$ fixou a diretriz, excessivamente curvilínea e acidentada, desde o limite da navegação do Púnguè (Fontesvila, atual Ponte do Púnguè) até à fronteira, com uma infraestrutura muito ligeira, com carris muito leves e uma bitola de $60 \mathrm{~cm}^{11}$

A construção começou em setembro de 1892 e contou exclusivamente com material britânico. Ironicamente, uma das locomotivas foi batizada de Rhodes.

DCD (24-03-1892), 17.

7 TNA, BT $58 / 7 / \cos / 944$ A.

8 Ibidem, вт 31/37658/36808. RT, 2846 (23-07-1892), 121; 100:3 (22-07-1911), 58.

9 TNA, FO 881/6570X. RT, 2860 (29-10-1892), 576. Mais tarde, a companhia obteve autorização para emitir duas séries adicionais de obrigações até 250 e 600 mil libras, sendo angariados 249,140 e 599,905 libras, respetivamente. Ibidem, вт 31/37658/36808. RT, 88:27 (30-12-1905, pp. 717-718); 100:3 (22-07-1911, p. 58). CORRESPONDÊNCIA, 1900, pp. 142-145.

10 De acordo com Sunderland (2012, vol. 1), tratava-se de James Mansergh, um especialista em ferrovias e hidráulica. Minutes of the Proceedings of the Institution of Civil Engineers, 161 (1905, pp. 350-354).

11 Distância entre carris. Na África do Sul, generalizara-se a bitola de $106.7 \mathrm{~cm}$. Na Europa, variava entre os $60 \mathrm{~cm}$ e os $167 \mathrm{~cm}$. Medidas inferiores eram reservadas a vias onde velocidade e capacidade de transporte não eram prioridades. Em teoria, a redução da bitola permitia baixar os custos de construção (Puffert, 2009, p. 16). Na Beira, toda a empreitada foi pensada para reduzir custos, dada a dificuldade em angariar o capital necessário (Lunn, 1997, pp. 19-20). 
O assentamento foi extremamente difícil em virtude da insalubridade, clima, orografia, flora e fauna do território (Ornelas, 1896; Pauling, 1969, pp. 131-138). Gao (1997, p. 42) refere que foi a linha que mais mortos provocou a nível mundial, embora esta afirmação pareça mais uma opinião do que um facto assente em fontes.

Apesar da presença do engenheiro Joaquim José Machado como fiscal, a obra avançou praticamente sem conhecimento das autoridades nacionais, de modo que a BeiraCo "mais parece uma dependencia da British South Africa ou antes do Sr. Cecil Rhodes, do que uma empreza exercendo os seus direitos e obrigações no territorio portuguez"12 - lamentava o administrador da CdM, Fontes Ganhado.

Em 1894, a linha avançara $170 \mathrm{~km}$ até Chimoio (a $100 \mathrm{~km}$ da fronteira), sendo a exploração assegurada pela L\&P. Naquele ano, iniciou-se o assentamento desde Fontesvila até à Beira. A BeiraCo estava praticamente falida e a BSAC não tinha capacidade para financiar a obra (Lunn, 1997, pp. 26-34), pelo que esta foi subconcessionada à $L \& P$, que, por sua vez, trespassou o contrato a uma nova firma, a Junction Co. Esta empresa tinha sede em Londres e um capital acionista de 62.5 mil libras e obrigacionista de 250 mil libras. O controlo britânico refletia-se na direção, onde três sócios de Rhodes (Van Laun, Wagner e Engbeare) abafavam qualquer veleidade do administrador português, Fontes Ganhado. ${ }^{13}$ A L\&P assegurou a construção, tendo recebido como pagamento a totalidade das ações. ${ }^{14}$

Estes acontecimentos foram novamente apresentados a Portugal e à CdM como factos consumados. Fontes Ganhado apenas podia lamentar-se: "é tal qual como se este caminho de ferro em vez de estar sendo construido no ponto mais acessivel e conhecido do nosso Territorio, fosse estabelecido n'um paiz extranho e longingquo". 15

A cdm receou que o interesse de Rhodes não se limitasse à ferrovia e se estendesse também aos territórios portugueses. A questão chegou ao parlamento pela voz do deputado da oposição, Mariano de Carvalho, que lembrou ainda a falta de fiscalização governamental sobre a obra, mas o governo preferiu realçar que a linha não trazia encargos ao tesouro e fazia parte de um processo diplomático confidencial, lembrando ainda o nefasto "effeito que produziria na Europa o não se construir aquelle caminho de ferro [...] e que

13 RT, 3008 (31-8-1895, p. 287).

14 TNA, BT/31/31400/44637.

15 CORRESPONDÊNCIA (1896, pp. 4-6). 
seria um desastre não deixarmos absolutamente concluido aquelle importantissimo melhoramento". ${ }^{16}$

Era a primeira vez em cinco anos que o caminho de ferro era debatido no parlamento, o que demonstra bem o secretismo com que o assunto era encarado pela elite política nacional. Aliás, noutras ocasiões, envolvendo outras vias-férreas metropolitanas menos importantes, as discussões foram bem mais frequentes, longas e inflamadas (Pereira, 2012, anexo 23).

O falhanço na construção da linha não trazia apenas desprestígio. $\mathrm{O}$ desastre aludido referia-se sobretudo ao incumprimento do tratado de 1891, que poria em causa as fronteiras então acordadas. Além disso, nesta altura, Portugal debatia-se com sérios problemas financeiros na sequência da bancarrota parcial de 1892 (Santos, 2001, pp. 202-204) e do escândalo financeiro da Companhia Real dos Caminhos de Ferro Portugueses (Fernandes, 2010, pp. 364-379). No ultramar, continuava em conflito jurídico com Inglaterra acerca do caminho de ferro de Lourenço Marques (Telo, 1991, 84-166); nas linhas de Mormugão e Ambaca pairava o espectro da desapropriação por não-pagamento aos investidores ingleses (Pereira, 2015, pp. 251-261; Navarro, 2018, pp. 283-293). Por tudo isto, e não apenas pelo putativo desleixo atribuído às autoridades nacionais (Navarro, 2018, pp. 396-397), o governo não pôs entraves à iniciativa britânica em Manica, independentemente das queixas da cdm e das eventuais ofensas ao brio nacional. Foi assim com alívio que, em 30 de junho de 1896, Portugal recebeu a confirmação de que Inglaterra considerava cumprida a obrigação de construir um caminho de ferro desde a Beira até à Rodésia, embora a linha só fosse concluída em 1897.

O custo rondou as 800 mil libras ou 3500 contos (Quadro 1), levantadas por obrigações. O cupão, porém, nunca foi pago em numerário entre 1893 e 1900. O pagamento era substituído por novas obrigações ou ações, contudo estas não conferiam direito de voto, o que manteve o poder na BSAC. ${ }^{17}$ Este, aliás, era o modelo financeiro da chartered, uma companhia sem atividade própria que atuava como concessionária gigante. Os contratos que obtinha eram distribuídos por subconcessionários inteiramente controlados por si.

16 DCD (05-05-1896, p. 1547).

17 RT, 2895 (01-07-1893, p. 21); 2921 (23-12-1893, p. 833); 2948 (07-07-1894, p. 25); 2999 (29-06-1895, p. 845); 3026 (04-01-1896, p. 24); 3034 (29-02-1896, pp. 288-289); 3051 (27-06-1896, p. 831); 3104 (03-07-1897, p. 21); 3182 (31-12-1898, p. 864); 3207 (24-06-1899, p. 820); 3233 (23-12-1899, p. 818); s/n (31-03-1900, p. 402). Em 1900, a BeiraCo reestruturou a dívida, dando o caminho de ferro como garantia (o que era ilegal à luz da lei portuguesa), todavia, o pagamento destas obrigações falhou novamente em diversos anos. TNA, BT 31/37658/36808. RT, (01-09-1900, p. 236); 91:26 (29-06-1907, p. 678); 97:26 (25-06-1910, p. 645). RG (03-01-1908, p. 19). 
O financiamento era garantido por obrigações, compradas maioritariamente pelos seus parceiros. ${ }^{18}$ Em caso de default, fazia-se uma troca de obrigações entre empresas da holding e quando uma das subconcessionárias esgotava o seu crédito ${ }^{19}$, havia outra que o assumia (Lunn, 1997, pp. 26-34).

Voltando à linha, o custo final foi extremamente baixo, com uma média quilométrica de 11 contos (refletindo a escolha da bitola), sobretudo quando comparados com os 37 contos/km da linha de Mormugão (Pereira, 2015, p. 252) os 34 de Ambaca (Navarro, 2018, p. 291, nota 86) ou mesmo os 18 de Lourenço Marques. ${ }^{20}$ A exploração foi confiada à L\&P e inaugurada sem conhecimento da cdm.

QUADRO 1

Custo do caminho de ferro da Beira

\begin{tabular}{lccccc}
\hline \multicolumn{1}{c}{ Secção } & $\begin{array}{c}\text { Extensão } \\
\text { (milhas) }\end{array}$ & $\begin{array}{c}\text { Extensão } \\
(\mathbf{k m})\end{array}$ & $\begin{array}{c}\text { Valor } \\
\text { (libras) }\end{array}$ & $\begin{array}{c}\text { Valor } \\
\text { (contos) }\end{array}$ & $\begin{array}{c}\text { Custo/km } \\
\text { (contos) }\end{array}$ \\
\hline Beira - Fontesvila & 35.5 & 57.13 & 175,726 & 790.77 & 13.84 \\
Fontesvila - Milha 75 & 75.0 & 120.70 & 169,200 & 761.40 & 6.31 \\
Milha 75 - Chimoio & 43.5 & 70.01 & 188,178 & 846.80 & 12.10 \\
Chimoio - Fronteira & 51.0 & 82.08 & 261,657 & 1177.46 & 14.35 \\
Total/média & 205.0 & 329.92 & 794,761 & 3576.42 & 10.84 \\
\hline
\end{tabular}

Fonte: RT, 3161 (6.8.1898), 177 (para os valores em milhas/libras). Valores em quilómetros/contos são cálculos do autor considerando: 1 milha $=1.609 \mathrm{~km} ; 1$ conto $=222.222$ libras (Mata, 1993).

A continuação da linha até Salisbury (atual Harare), a capital da Rodésia, foi entregue à MashonalandCo (formada em 1897 pela BSAC), que a inaugurou em maio de 1899, mas numa bitola diferente da Beira: 106,7 cm. Para anular a baldeação na fronteira, decidiu-se rebitolar a linha portuguesa. Para tal, a BeiraCo emitiu 850 mil libras em obrigações, todas tomadas pela MashonalandCo e garantidas pela BSAC, numa operação típica do grupo ${ }^{21}$, e contratou novamente os Paulings. A tarefa foi atrasada pela guerra anglo-boer,

18 Na Beira, houve também investidores independentes que viram as suas expectativas defraudadas e recorreram aos tribunais. RT, 89:2 (13-01-1906, p. 52); 89:5 (03-02-1906, pp. 140-141); 91:7 (16-02-1907, p. 194).

19 Em 1905, as obrigações da BeiraCo estavam cotadas a 10-14\% do seu valor nominal. RT, 87:25 (24-06-1905, p. 626).

20 AHU, maço $27561 \mathrm{~B}$.

21 RT, 3196 (o8-04-1899), 445; 3419 (18-07-1903), 52; 88:27 (30-12-1905), 717-718. TNA, BT $31 / 37658 / 36808$. A MashonalandCo tinha prioridade sobre todos os outros credores e acionistas, até 42,500 libras/ano (5\% de juro). CORRESPONDÊNCIA, 1900, 142-145. 
mas foi concluída em agosto de 1900.22 A exploração de toda a linha da Beira a Salisbury foi confiada à MashonalandCo por um período inicial de quatro anos. $\mathrm{O}$ acordo estabeleceu um through-traffic arrangement que contribuiria para uma eficaz circulação transfronteiriça, mas foi estabelecido sem anuência da cdm e perante a surpresa desta e das autoridades locais.

\section{A OPERAÇÃO}

A L\&P geriu a exploração da linha desde 1894 até 1900, quando a passou para a MashonalandCo. Os dados da operação são escassos, uma vez que os Paulings não os partilhavam, apesar de a isso estarem obrigados (Portaria de 6 de maio de 1896). ${ }^{23}$ Todavia, a fiscalização foi sempre incipiente por própria responsabilidade do governo português, que, apesar dos pedidos da cdm e das autoridades locais, sempre recomendou prudência aos fiscais para evitar atritos com a companhia. ${ }^{24} \mathrm{~A}$ CdM apenas sabia alguns dados gerais sobre receita, despesa e transporte de passageiros e mercadorias (Quadro 2). Apesar de muito genéricos, os números não eram atrativos. $\mathrm{O}$ tráfego era reduzido, o que forçou os Paulings a manter as tarifas altas e a cortar na manutenção, piorando o serviço, quer durante a sua exploração, quer nos primeiros anos da operação pela MashonalandCo (Lunn, 1997, pp. 36-41).

Em ambas as gerências, a cdM sabia que as tarifas cobradas eram superiores às do Cabo. Embora a medida se justificasse (uma vez que a rede do Cabo era estatal, beneficiava das economias de escala decorrentes de um tráfego muito mais volumoso e possuía uma estrutura de custos mais limitada), infringia o contrato original de concessão. ${ }^{25}$ Porém, o governo autorizou aquelas taxas por um período limitado de tempo, autorização que foi sendo renovada ao longo dos anos. ${ }^{26}$

22 RT, s/n (22-12-1900, p. 699).

23 LEgIS, 2, 909. Para Machado, a portaria não teria efeitos práticos, pois o regulamento respeitava a ferrovias concedidas pelo Estado e não por companhias majestáticas. Antevia uma "soffrivel trapalhada" com benefícios para a BeiraCo "que continuará a proceder segundo a sua phantasia" (CORRESPONDÊNCIA, 1896, pp. 247-248). Optou-se por elaborar novo regulamento, acordado entre a cdm e a BeiraCo, contudo, este processo arrastou-se por meses (CORRESPONDÊNCIA, 1896, pp. 308-311) e, quando foi resolvido em 1897, verificou-se que o regulamento era inaplicável. AHU, maço 3033 1A, relatório de 02-06-1900.

24 CORRESPONDÊNCIA (1897, pp. 83 e 211-212; 1900, pp. 308-310).

25 CORRESPONDÊNCIA (1895, pp. 93-95; 1898, pp. 23-29 e 60-73).

26 TNA, FO 367/17, cartas de 07-07-1898 e 08-07-1898. AHU, maço 2550 1B, cartas de 03-06-1901 e 19-06-1901. A partir de 1902, a MashonalandCo aceitou a fiscalização da cdM em troca da manutenção dos valores das tarifas. CORRESPONDÊNCIA (1902, pp. 102-103). 
QUADRO 2

Dados estatísticos da operação, 1893-1898

\begin{tabular}{cccccccc}
\hline \multirow{2}{*}{ Ano } & Receita & Despesa & Líquido & \multicolumn{3}{c}{ \# Passageiros } & Mercado- \\
\cline { 2 - 6 } & & (libras) & & Ascendentes & Descendentes & Totais & rias (t) \\
\hline $1893^{*}-1894$ & 20,123 & 26,263 & $-6,140$ & - & - & - & - \\
1895 & 51,617 & 48,173 & 3,444 & - & - & - & - \\
1896 & 83,134 & 65,489 & 17,645 & - & - & - & - \\
$1897^{*}$ & 96,899 & 96,431 & 468 & - & - & - & - \\
$1897^{* *}$ & - & - & - & 708 & 846 & 1,554 & 8,741 \\
1898 & - & - & $-8,220$ & 1,708 & 1,664 & 3,372 & 18,278 \\
\hline
\end{tabular}

Notas: ${ }^{*}$ Até setembro. ${ }^{* *}$ Desde outubro.

Fonte: Companhia (1902, p. 372). Correspondência (1898, p. 212; 1901, pp. 172-175). RT, 3161 (06-08-1898, p. 177).

Esta questão não era meramente comercial (como argumenta Lunn, 1997, pp. 36-41), mas também tecnodiplomática, uma vez que determinava a direção dos fluxos ferroviários para a Beira ou para os portos sul-africanos. Rhodes não colocara o futuro do transporte da Rodésia apenas na Beira, sobretudo após perceber que Londres não lhe permitiria anexar o território português (Lunn, 1997, p. 18). A partir de 1893, procurou estender um ramal até Vryburg, na rede do Transval, que se prolongava até às colónias do Cabo e Natal (Mapa 1). Para tal, fundou a RhodesiaCo, inteiramente financiada pela BSAC. Em novembro de 1897 , a linha chegava a Bulawayo, o que deixava a Rodésia a apenas cinco-seis dias do Cabo. A ligação à capital Salisbury foi adiada por causa da Segunda Guerra dos Boers (1899-1902), mas realizou-se em 1902. Nos anos seguintes, a linha cresceu até Wankie (atual Hwange), Victoria Falls, Livingstone e Katanga (no Congo), atingindo ricas jazidas de minerais e metais preciosos (Hanes III, 1991, pp. 41-50; Lunn, 1997, pp. 23-24).

Embora a Beira ficasse muito mais perto da Rodésia, era um ancoradouro estrangeiro, que ia beneficiar dos investimentos da BSAC, prejudicando os ancoradouros dos territórios ingleses. Politicamente, a BSAC tinha interesse em aproximar-se das colónias sul-africanas ${ }^{27}$, mas, por outro lado, corria o risco de descontentar o comércio da Mashonalândia e de Salisbury, que preferia a opção Beira (Gao, 1997, pp. 112-116). Por fim, drenar Manica e Sofala de movimento poderia convencer o governo português a abdicar daqueles territórios ou mostrar a sua incapacidade para os colonizar eficazmente. 
A problemática não era nova para Portugal, que já a tinha experienciado anteriormente, tanto no ultramar como na Europa. Na Península Ibérica, Portugal construíra uma rede virada para Espanha, com cinco ligações transnacionais, contudo, graças a combinações de tarifas das companhias espanholas, o tráfego era insignificante (Pinheiro, 1995, pp. 340-344; Vidal, 1995, pp. 351-357). Na Índia, o caminho de ferro de Goa colocava o sul da Índia Britânica em contacto direto com o porto de Mormugão, mas as firmas ferroviárias anglo-indianas impuseram uma política tarifária que beneficiava o trânsito para Bombaim (Pereira, 2015, pp. 258-259). ${ }^{28}$ No sul de Moçambique, o movimento do Transval era cobiçado por Lourenço Marques e por Durban, Port Elizabeth, East London e Cabo. Apesar da concorrência, Portugal conseguiu garantir uma generosa fatia do tráfego, pois possuía um poderoso trunfo: o fornecimento de mão de obra às minas do Transval, o qual ameaçava cortar em caso de desvio artificial do tráfego transvaliano (Bouene, Santos, 2006, pp. 243-247).

$\mathrm{Na}$ Beira, o tráfego estava ainda dependente da política interna da África do Sul. Em 1895, Rhodes organizou um golpe militar (Jameson Raid) para obter o controlo político do Transval. O movimento falhou, o que desacreditou Rhodes perante o governo inglês e lhe dificultou o uso da rede férrea transvaliana (Hanes III, 1991, pp. 47-48; Lunn, 1997, pp. 22-23; Robinson, 1991, pp. 181-182). Além disso, uma revolta na Matabelelândia forçou-o a virar atenções para a linha da Beira. ${ }^{29}$ Segundo Ornelas (1896), a partir de maio de 1896 , a BeiraCo passou a transportar exclusivamente bens da BSAC. Mais tarde, em finais da década de 1890, surgiu um fator que podia beneficiar o porto nacional: a guerra anglo-boer. No início do conflito, os boers tomaram Vryburg e Mafeking (atual Mahikeng), cortando o nó ferroviário entre a África do Sul e a Rodésia (Croxton, 1982, pp. 56-57), que assim teve que se virar para a Beira para aceder ao mar. Em janeiro de 1900, a BSAC pede aos Paulings que assegurassem o transporte de armas, munições e soldados para a Rodésia, comprometendo-se a pagar qualquer indemnização exigida pelos portugueses (o transporte de material de guerra era proibido à luz do tratado de 1891). ${ }^{30}$

28 Além das tarifas, havia outros fatores que afastavam o tráfego: falta de equipamentos nos portos, ausência de carreiras regulares de vapores e funcionamentos processuais diferentes. A linha e porto da Beira sofriam também destes males, além de que os serviços marítimos para a África do Sul preferiam a rota do Cabo à rota do Suez. CORRESPONDÊNCIA (1903, pp. 135-137). 29 RT, 3028 (18-01-1896, p. 87; 3031 (08-02-1896, p. 196).

30 TNA, WO 32/7920. A operação exigiu uma planificação detalhada, pois a linha tinha capacidade limitada e estava em pleno processo de rebitolagem. Mesmo assim, registaram-se embaraços no transporte, provocados pelas limitações do caminho de ferro e pelo clima inóspito da região. TNA, WO 32/7939, wO 32/7944. 
Terminado o conflito com a anexação do Transval pelo Império Britânico, a geografia de transporte da região aparentemente beneficiava a rota sul. A RhodesiaCo e os caminhos de ferro sul-africanos imediatamente baixaram as tarifas, o que levou ao cancelamento de muitos fretes na Beira. $\mathrm{O}$ transporte para os portos sul-africanos tornou-se mais barato, apesar de a distância ser muito superior (Lunn, 1997, pp. 36-41). Um negociante de Salisbury, J. Geil, confirmava que "at present the frozen meat trade at Beira was of very little value, while all west of Salisbury can be supplied as advantageously from the south". ${ }^{31}$ Para contrariar a situação, as forças vivas de Salisbury e de Manica e Sofala fizeram pressão para reduzir os preços, de modo que a Beira pudesse "reap the benefit of the geographical advantage it possesses". ${ }^{32}$

Em 1904, terminou o arrendamento da operação à MashonalandCo e o governo aproveitou a oportunidade para tentar baixar as tarifas. ${ }^{33}$ A situação era delicada, pois qualquer tomada de posição agressiva iria certamente ser respondida com um aumento tarifário no troço que continuava a linha na Rodésia e com uma rebaixa na rota para sul ou com a imposição de obstáculos à livre circulação na fronteira. Era praticamente forçoso manter a operação unificada na MashonalandCo ${ }^{34}$, até porque Portugal tinha o bom exemplo do caminho de ferro de Mormugão, cujo movimento transnacional aumentara assim que fora arrendado em 1902 à companhia que a continuava em solo indo-britânico (Pereira, 2015, pp. 260-261).

De qualquer maneira, a negociação não chegou a bom termo e a cdm e a BeiraCo acordaram um modus vivendi (sucessivamente renovado até $1909^{35}$ ) que mantinha a operação na MashonalandCo e baixava as tarifas, ainda assim para níveis superiores às do Cabo. ${ }^{36}$ De imediato, as gestões ferroviárias do Cabo e Natal reagiram com novas rebaixas, prometendo que "if necessary, they were prepared to engage in a rate war. ${ }^{37} \mathrm{O}$ RT explicava claramente a situação

31 DRO, D3287/RTC/2/26.

32 Idem, D3287/RTC/2/27 e 165. Ver também AHU, maço 2550 1B, cartas de 28-07-1904 e 30-12-1904 e notícia de 17-12-1904. CORRESPONDÊNCIA (1903, pp. 131-134; 1904, pp. 135-140). 33 AHU, maço 2550 1B, carta de 17-12-1904 e telegrama de 21-12-1904. CORRESPONDÊNCIA (1904, pp. 130-134).

34 AHU, maço $4991 \mathrm{~F}$, parecer de 1904.

35 Idem, maço 2550 1B, despachos de 16-03-1905, p. 14 e 30-05-1905, 27-06-1905, 29-11-1907 e 26-11-1908.

36 Idem, maço 2550 1B, cartas de 21 e 22-01-1905 e relatório de 24-07-1905. RT, 88:5 (2907-1905, p. 138). CORRESPONDÊNCIA (1905, p. 68). Se, por um lado, a intervenção da MashonalandCo agilizava a operação ferroviária, por outro, emperrava a negociação, uma vez que a BeiraCo não podia decidir nada sem primeiro a consultar.

37 The Natal Advertiser (02-08-1905). 
quando descrevia que "a strong feeling exists in Cape Colony and Natal against efforts being made to continue to divert legitimate trade from British colonial ports to Delagoa Bay [Lourenço Marques] and Beira" ${ }^{38}$ A BeiraCo sugeriu a construção de um novo porto na Beira (financiada por capitalistas ingleses) para melhorar o tráfego na linha. A cdm começou por recusar, mas, em 1911, a JunctionCo aumentou o seu capital para angariar fundos junto da BSAC. ${ }^{39}$ Contudo, nada seria feito até ao fim da Primeira Guerra Mundial.

Os números da operação ilustram as discussões anteriores. As figuras 1 a 4 demonstram que o tráfego na linha Beira-Salisbury (tanto de bens como de passageiros) só começou a crescer constantemente a partir de 1908. Desde essa data, o material de construção praticamente desaparece dos vagões, mas é compensado pelo aumento dos carregamentos de minério e bens de carácter geral. Esta evolução refletiu-se positivamente na receita. A despesa também subiu, mas não de forma proporcional, pelo que o lucro aumentou, o que possibilitou pagar o juro devido aos obrigacionistas (com retroativos) a partir de $1911 .{ }^{40}$

A redução de tarifas explica parcialmente esta evolução, mas não é a principal razão. Por um lado, a diminuição verificou-se desde 1905 e foi, além disso, contrariada por igual medida na rota para sul (Gao, 1997, pp. 112-116). Antes de 1908 , a operação só não foi pior, em virtude do transporte dos materiais de

FIGURA 1

Evolução da receita, despesa e lucro operacional da linha Beira-Salisbury, 1901-1914 (libras).

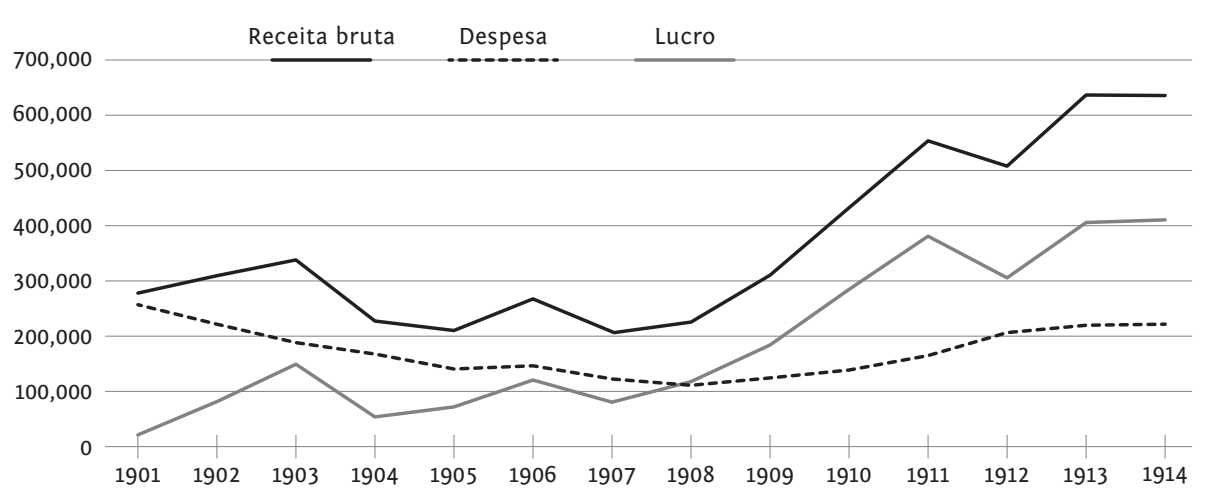

Fonte: AHU, maço 579 1E; DRO, D3287, 11; RG (9-10-1914, p. 414).

38 RT, 88:5 (19-08-1905, p. 220).

39 TNA, FO 367/17, relatório de 21-08-1906. AHU, maço 579, 1E, relatório de 12-10-1914; maço 2550 1B, cartas de 01 e 25-03-1909. RT, 96:22 (27-11-1909, p. 549); 97:18 (30-04-1910, p. 456); 99:26 (30-12-1911, pp. 660-661).

40 RG (27-12-1912, pp. 749-750). RT, 99:17 (29-04-1911, p. 411); 99:26 (30-12-1911, p. 661). 
FIGURA 2

Evolução do transporte de passageiros (escala da direita) e mercadorias (esquerda, em t) na linha Beira-Salisbury, 1901-1914.

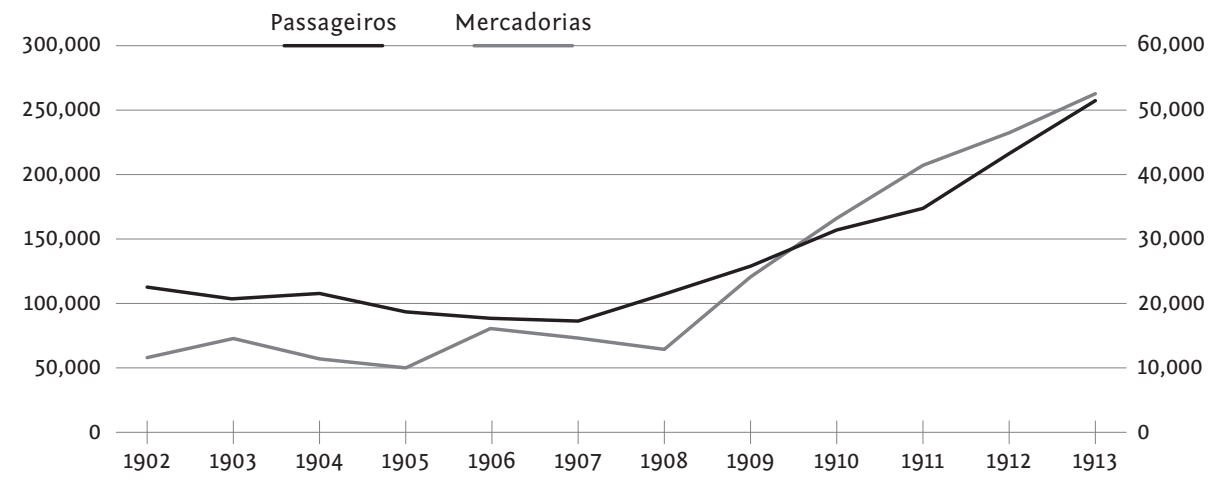

Fonte: AHU, maço 579 1E.

FIGURA 3

Componentes do transporte de mercadorias na linha Beira-Salisbury, 1901-1914.

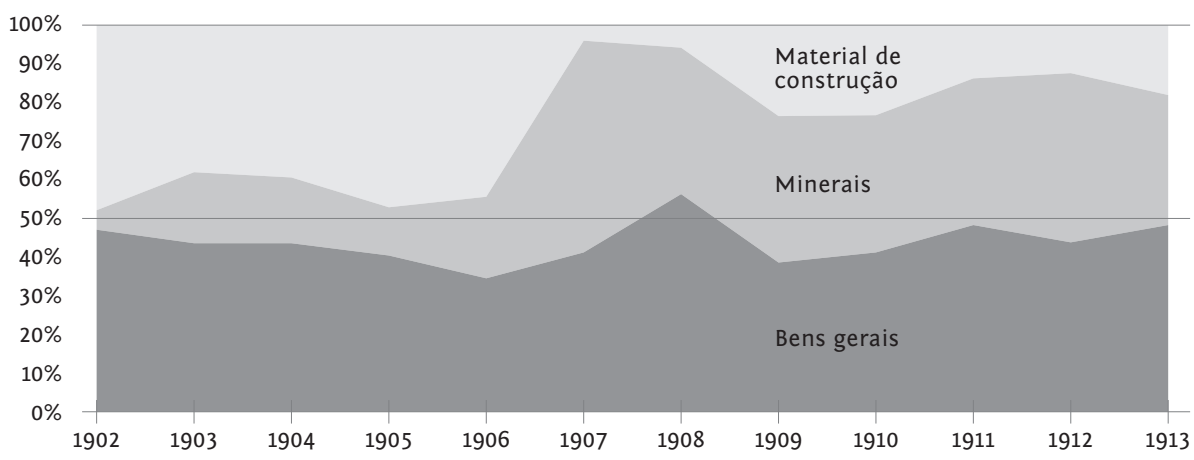

Fonte: AHU, maço 579 1E.

construção para as linhas da Rodésia. ${ }^{41}$ Mais importante foi o desenvolvimento de produções agrícolas em Manica e Sofala, que exportavam milho para fora de África e para o território da BSAC (Direito, 2013, pp. 200-202), e o crescimento económico da Rodésia e da África do Sul, que gerou um tráfego tal que a rota ferroviária para sul não conseguiu suportar (Lunn, 1997, pp. 36-41). ${ }^{42}$

41 RG (18-03-1910), 321; (o6-09-1912, p. 283).

42 Idem (20-10-1910, pp. 404-407); (28-10-1911, pp. 1-96); (o8-03-1912, p. 269); RT, 100:3 (22-07-1911, p. 58). 
FIGURA 4

Evolução das milhas percorridas pelos comboios da linha Beira-Salisbury, 1901-1914.

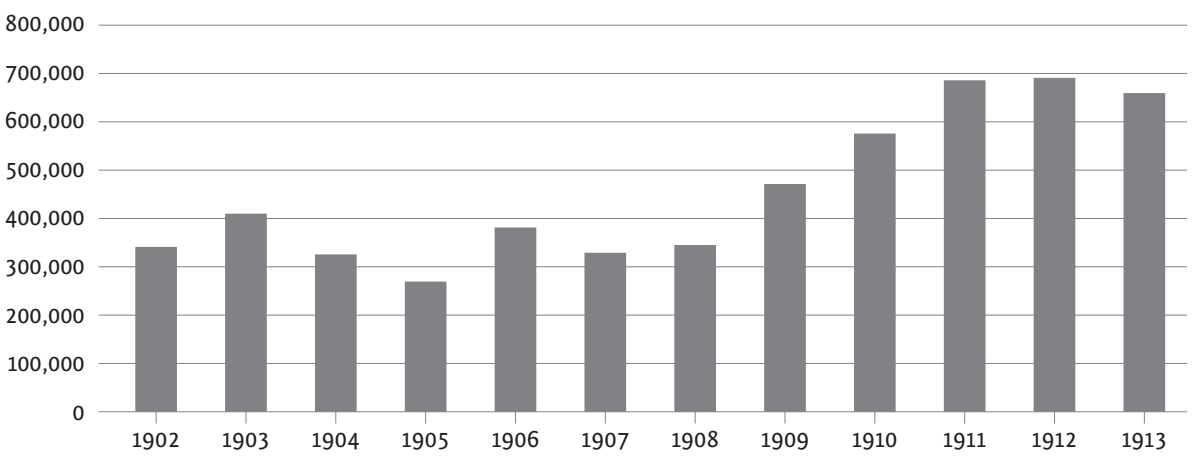

Fonte: AHU, maço 579 1E.

Assim, as colónias britânicas tiveram que partilhar o movimento com a linha e porto nacionais, ainda que, de acordo com Lunn (1997, pp. 36-43), reservassem para si as mercadorias mais valiosas. A inflexão no trânsito foi tão notória que, em 1910, levou a Union Castle Company a estabelecer uma carreira direta de vapor entre a Beira e Inglaterra pelo Suez ${ }^{43}$ e, em 1911, em Moçambique, forçou a BeiraCo a adquirir mais material trator. ${ }^{44}$

Apesar de ser a saída natural do landlocked country rodesiano, a verdade é que eram a linha e porto da Beira que estavam mais dependentes do território vizinho, de modo que quando uma seca afetou a colónia britânica, em 1913, o movimento e receita ferroviários ressentiram-se. ${ }^{45}$

É difícil demonstrar exatamente qual o efeito que aquelas infraestruturas tiveram no território nacional. Navarro (2018, p. 399), baseando-se em alguns relatórios coevos, afirma que não concorreram para o incremento da atividade agrícola e económica do território. Newitt (1981, p. 34), pelo contrário, assevera que contribuíram para o desenvolvimento de Manica e Sofala, embora apenas refira que auxiliava os fazendeiros locais a mercadejar os seus produtos. Já vimos como Direito (2013, pp. 200-202) refere que era através da via-férrea que o crescimento da produção agrícola de Manica e Sofala era escoado. Amaral (1969, pp. 76-80) avança dados mais substanciais sobre a cidade e porto da Beira que, indiscutivelmente, cresceram durante o período analisado. 
Igualmente indiscutível é que o movimento portuário cresceu enormemente de uns escassos 192 contos em 1892 para um máximo de 141 mil contos em 1913 (Figura 5). As fotos 1 a 4 atestam visualmente o desenvolvimento do ancoradouro, por onde transitaram também milhares de pessoas, sobretudo entre 1895 e 1901 (entre 1899 e 1901, militares em trânsito para a Guerra dos Boers).

FIGURA 5

Evolução do movimento do porto da Beira (em contos), agosto de 1892-1900 e 1907-1914 .

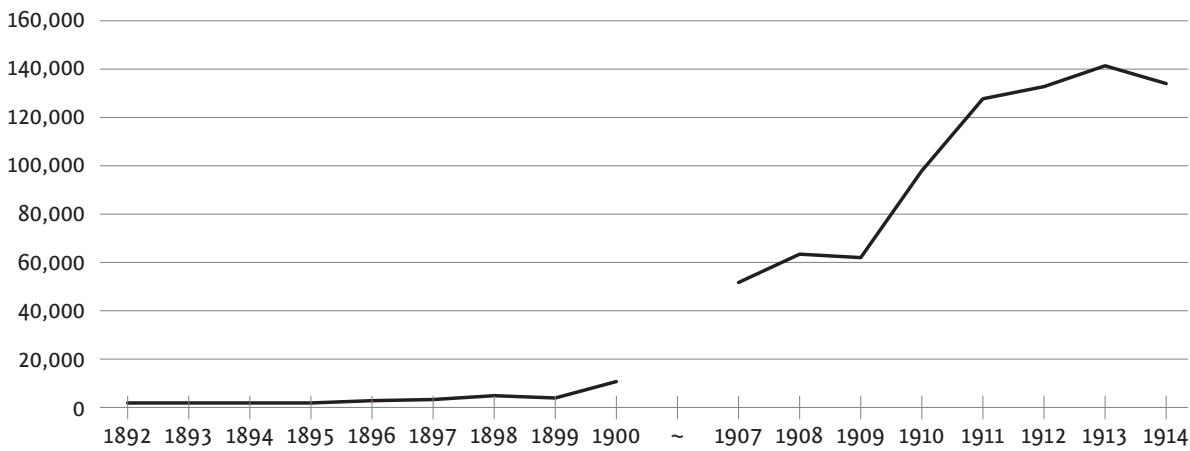

Fonte: Boletim da Companhia de Moçambique (1893-1910); Boletim do Governo do Território da Companhia de Moçambique (1911-1915); Boletins Estatísticos do Movimento Comercial e Marítimo no Território de Manica e Sofala (1908 e 1909); Boletins Estatísticos do Movimento Comercial e Marítimo no Território da Companhia de Moçambique (1910).

FIGURA 6

Movimento de passageiros na Beira, segundo semestre de 1892-1901 e 1907-1910.

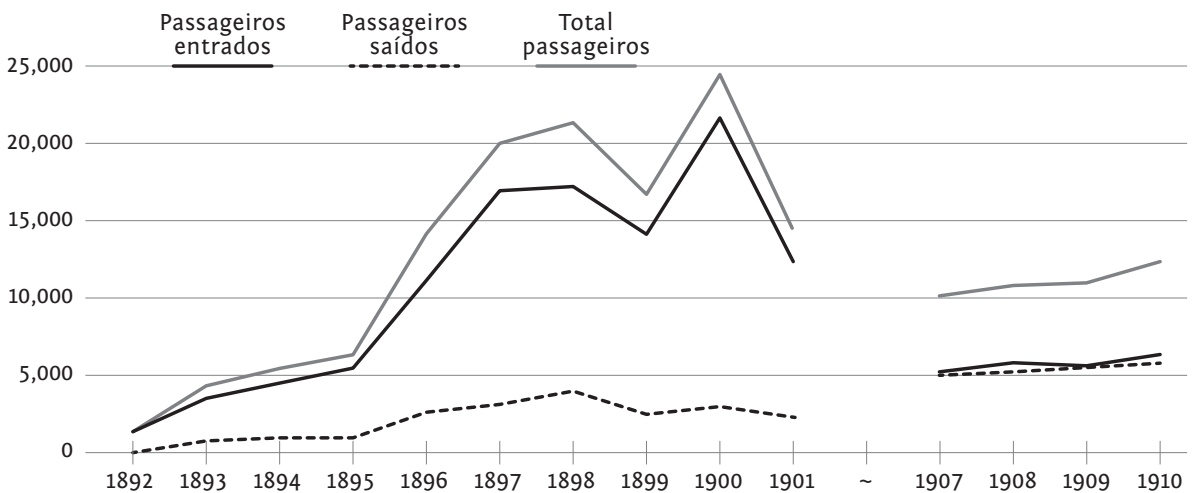

Fonte: Boletim da Companhia de Moçambique (1893-1910); Boletim do Governo do Território da Companhia de Moçambique (1911-1915); Boletins Estatísticos do Movimento Comercial e Marítimo no Território de Manica e Sofala (1908 e 1909); Boletins Estatísticos do Movimento Comercial e Marítimo no Território da Companhia de Moçambique (1910) e Companhia (1902, pp. 334-335). 


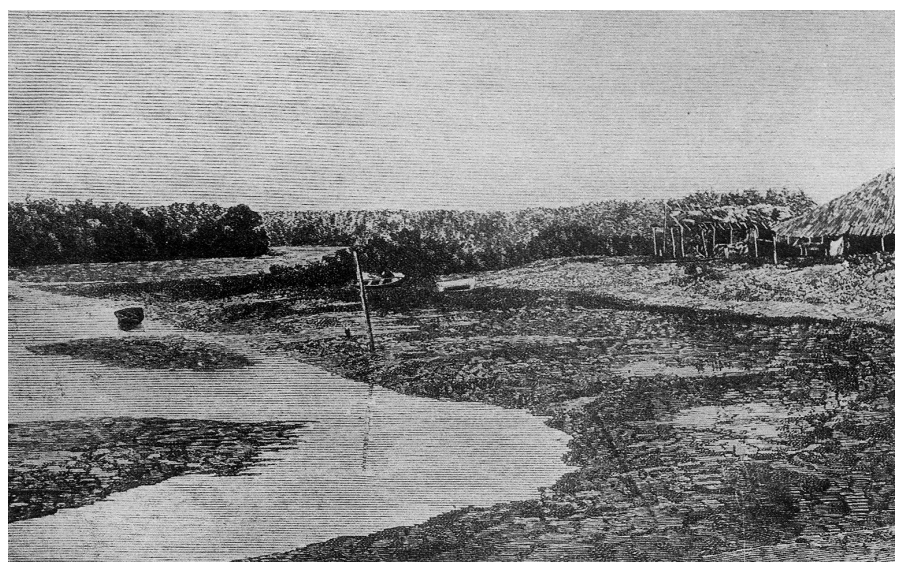

FOTO 1

Porto da Beira

em 1891.

Fonte:

Companhia (1934, p. 49).

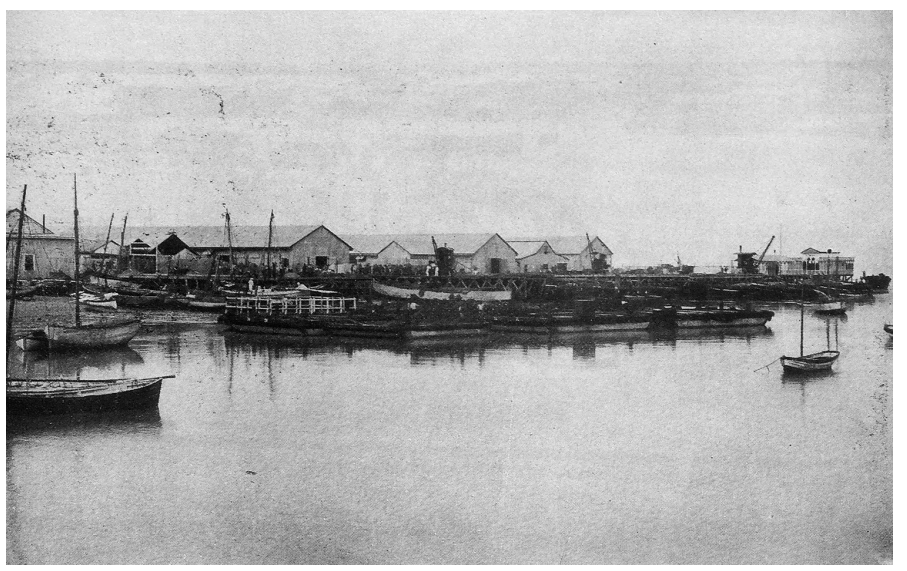

FOTO 2

Porto da Beira

em 1898.

Fonte:

Companhia (1934, p. 53).

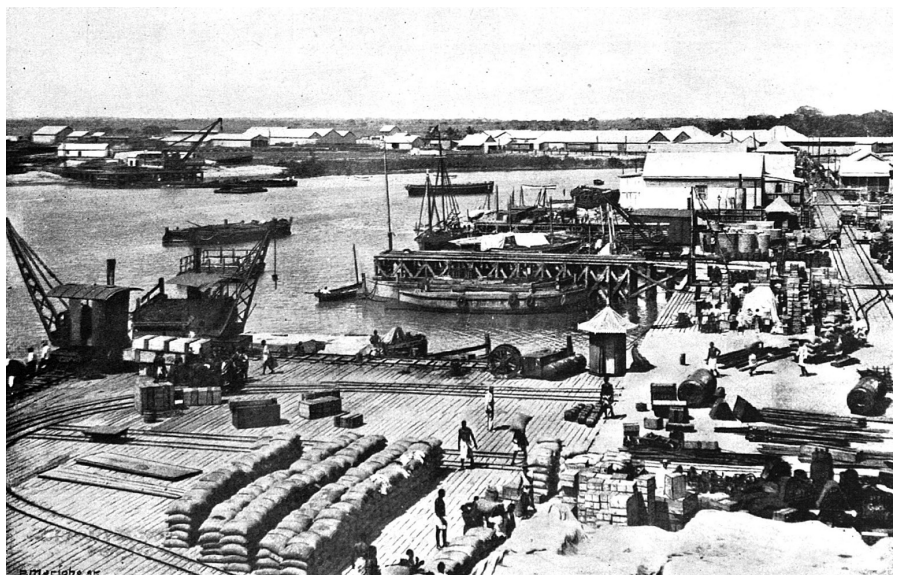

FOTO 3

Cais da Alfândega,

na Beira, c. 1902.

Fonte:

Companhia (1902). 


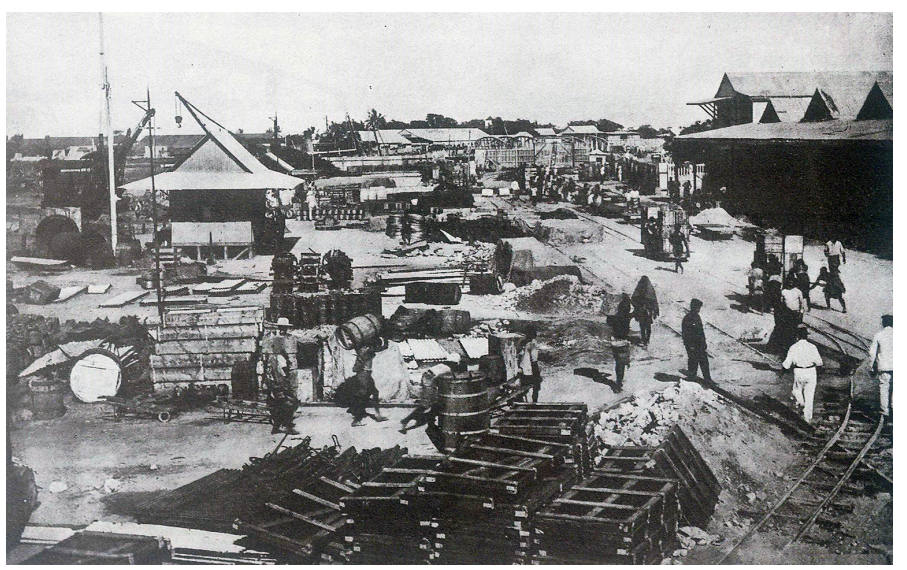

FOTO 4

Porto da Beira

em 1911.

Fonte:

Companhia (1934, p. 58).

Tendo em conta que o número de passageiros entrados ultrapassa largamente o de saídos (Figura 6), posso especular que o porto (em conjunção com o caminho de ferro) contribuiu para o povoamento da cidade e território (Amaral, 1969, p. 80).

Os dados têm uma lacuna entre 1900 e 1907 que limita a análise. De qualquer modo, os números disponíveis indicam que até 1900 a importação foi o principal fluxo do porto, o que não surpreende dado que o grosso da construção decorreu neste período (Figura 7). O pico de registos em trânsito (entrados na Beira, mas com destino final fora do território português, maioritariamente a Rodésia) em 1895 fica provavelmente a dever-se ao transporte de material ferroviário para o território da BSAC (que foi revertido nos anos seguintes, devido à aproximação da rede ferroviária rodesiana da África do Sul). A partir de 1907, as mercadorias em trânsito tornam-se dominantes. Há sete anos que a ligação Beira-Salisbury era operada pela MashonalandCo, tornando-se assim um corredor para abastecer a Rodésia de produtos importados (é improvável que estas mercadorias em trânsito chegassem ao território da BSAC por outros meios que não a ferrovia). A relevância da importação diminuiu, polarizada com o surgimento de dois novos fluxos, a baldeação (trasfega direta de mercadorias de navios para comboios) e a cabotagem, que tanto podiam respeitar a importações, exportações ou trocas internas, mas que demonstram o desenvolvimento das condições portuárias da Beira. O peso dos fluxos para fora do território (exportação com origem em Moçambique ou reexportação com origem fora da colónia portuguesa) continuou pouco relevante.

Um exame ao rendimento da alfândega da Beira complementa a análise, embora, na ausência das taxas impostas a cada movimento, deixe algumas dúvidas (Figuras 8 e 9). 
FIGURA 7

Discriminação dos movimentos registados no porto da Beira, agosto de 1892-1900 e 1907-1914.

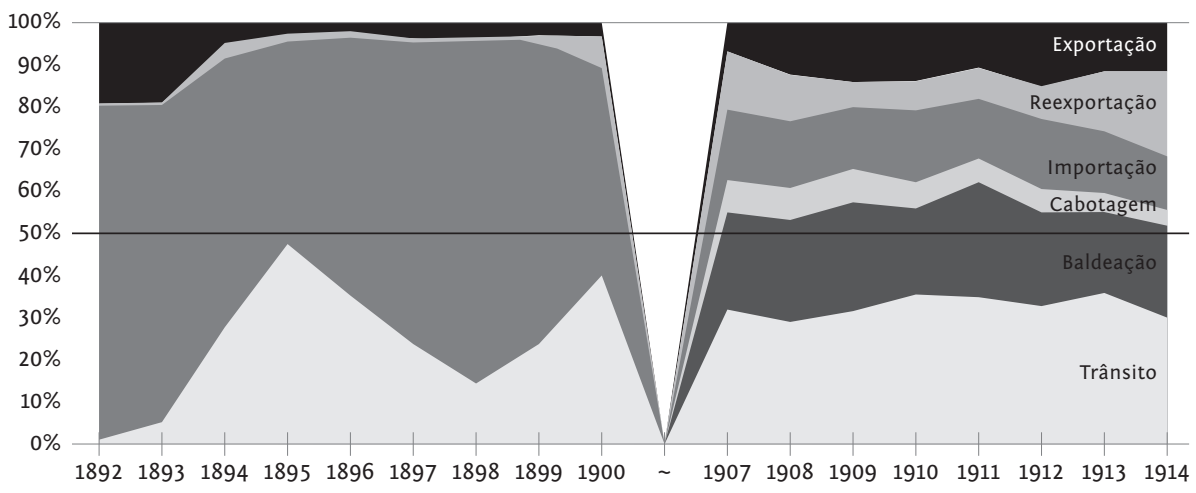

Fonte: Boletim da Companhia de Moçambique (1893-1910); Boletim do Governo do Território da Companhia de Moçambique (1911-1915); Boletins Estatísticos do Movimento Comercial e Marítimo no Território de Manica e Sofala (1908 e 1909); Boletins Estatísticos do Movimento Comercial e Marítimo no Território da Companhia de Moçambique (1910).

\section{FIGURA 8}

Evolução da receita da alfândega da Beira (em contos), segundo semestre de 1892-1914.

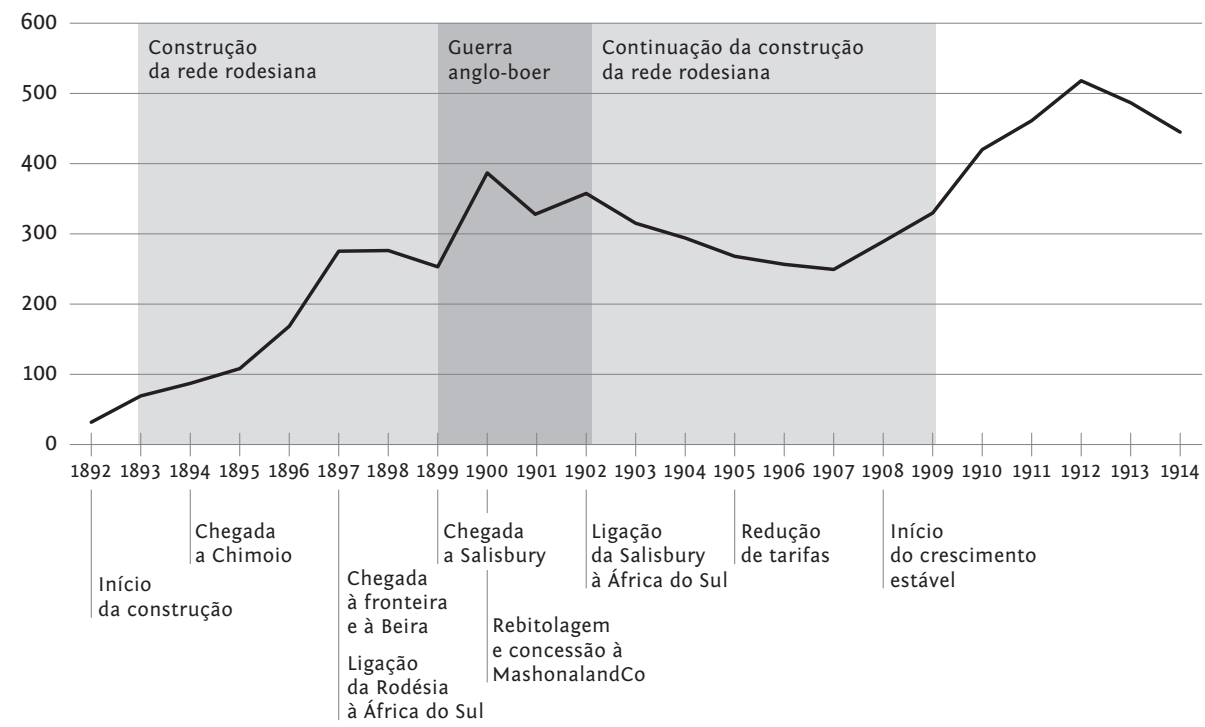

Fonte: Boletim da Companhia de Moçambique (1893-1910); Boletim do Governo do Território da Companhia de Moçambique (1911-1915); Boletins Estatísticos do Movimento Comercial e Marítimo no Território de Manica e Sofala (1908 e 1909); Boletins Estatísticos do Movimento Comercial e Marítimo no Território da Companhia de Moçambique (1910). 
FIGURA 9

Componentes da receita da alfândega da Beira, segundo semestre de 1892-1914

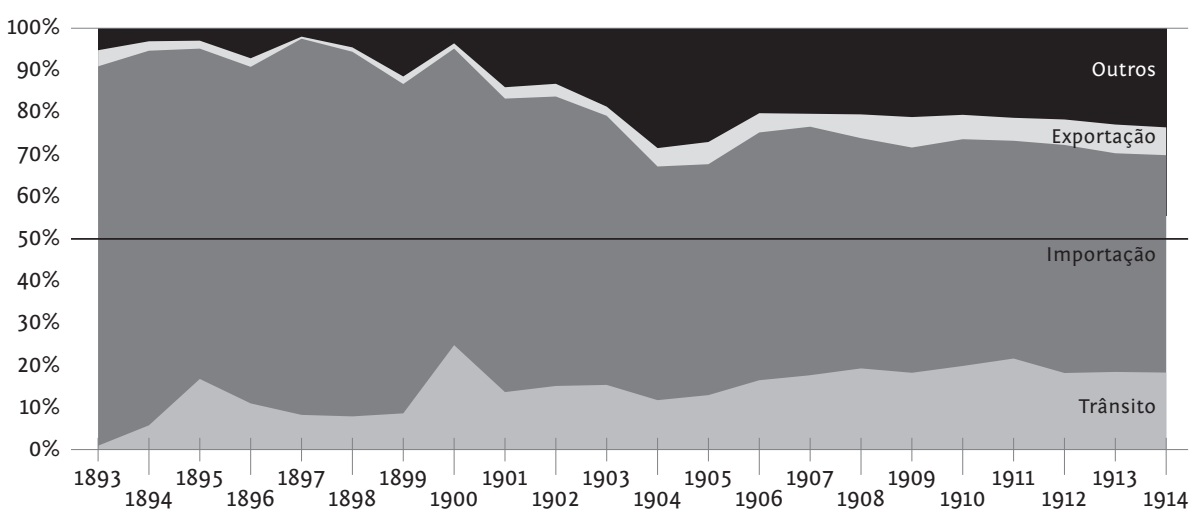

Fonte: Boletim da Companhia de Moçambique (1893-1910); Boletim do Governo do Território da Companhia de Moçambique (1911-1915); Boletins Estatísticos do Movimento Comercial e Marítimo no Território de Manica e Sofala (1908 e 1909); Boletins Estatísticos do Movimento Comercial e Marítimo no Território da Companhia de Moçambique (1910).

As receitas aduaneiras conheceram igualmente um enorme crescimento (34 contos em 1892 contra 519 contos em 1912), graças sobretudo aos bens importados. O tratado de 1891 limitava as taxas sobre os bens em trânsito e em reexportação a um máximo de $3 \%$, ao passo que isentava de impostos o material de construção de estradas, telégrafos e ferrovias. ${ }^{46}$ Contudo, até 1899, a construção foi o fator determinante. Embora o material para a obra estivesse isento de direitos, a empreitada justificava sempre a importação de outros materiais que não escapavam ao fisco. Aliás, é sintomático que a receita da alfândega tenha estagnado precisamente quando terminou a construção.

A Segunda Guerra dos Boers cortou a ligação entre a África do Sul e a Rodésia, que teve assim que se virar para a Beira, o que se refletiu num aumento da receita e do peso dos rendimentos sobre as mercadorias em trânsito. Terminado o conflito favoravelmente aos interesses britânicos, registou-se uma diminuição dos réditos aduaneiros. A redução de tarifas ferroviárias de 1905 pouco fez para alterar a situação, que só se inverteu a partir de 1907-1908, devido ao já citado crescimento económico da Rodésia. A dependência da Beira em relação ao seu vizinho fica também demonstrado no decréscimo da receita alfandegária a partir de 1913, em consequência da seca que assolou a Rodésia. 


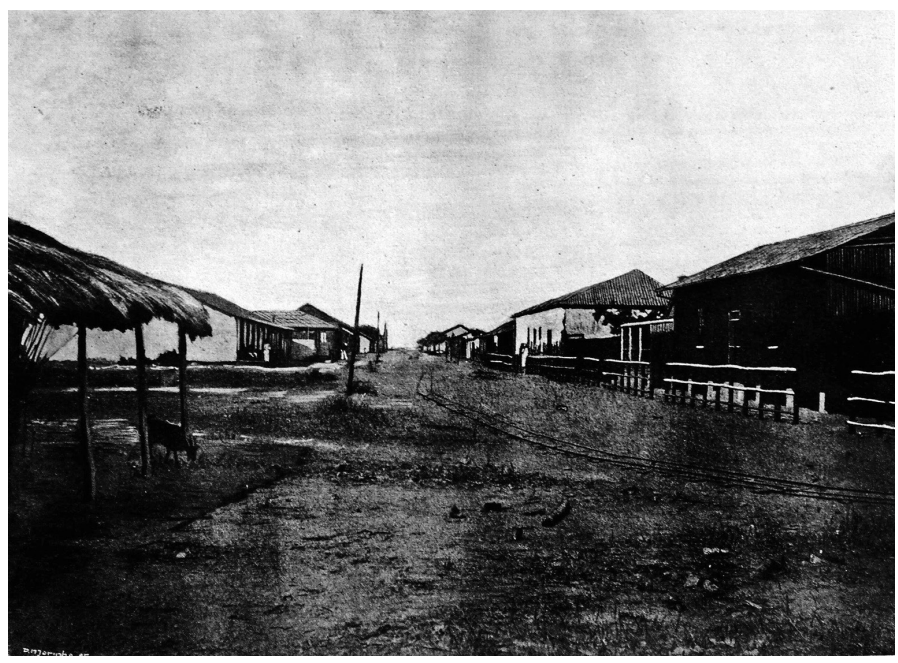

FOTO 5

Rua do Conselheiro Castilho, na Beira, em 1892

Fonte: Companhia (1902).

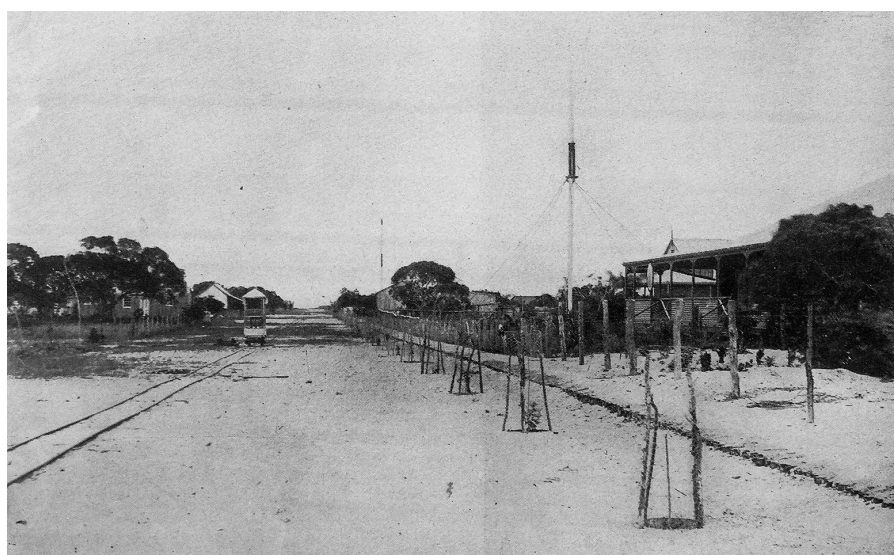

FOTO 6

Avenida D. Carlos, na Beira, em 1895.

Fonte:

Companhia (1934, p. 14).

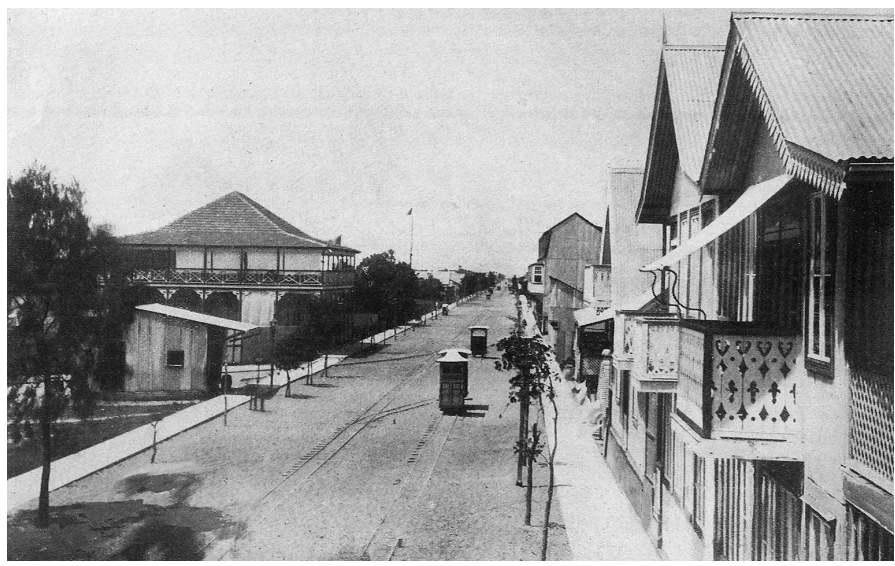

FOTO 7

Avenida D. Carlos, na Beira, em 1899.

Fonte:

Companhia (1934, p. 16). 


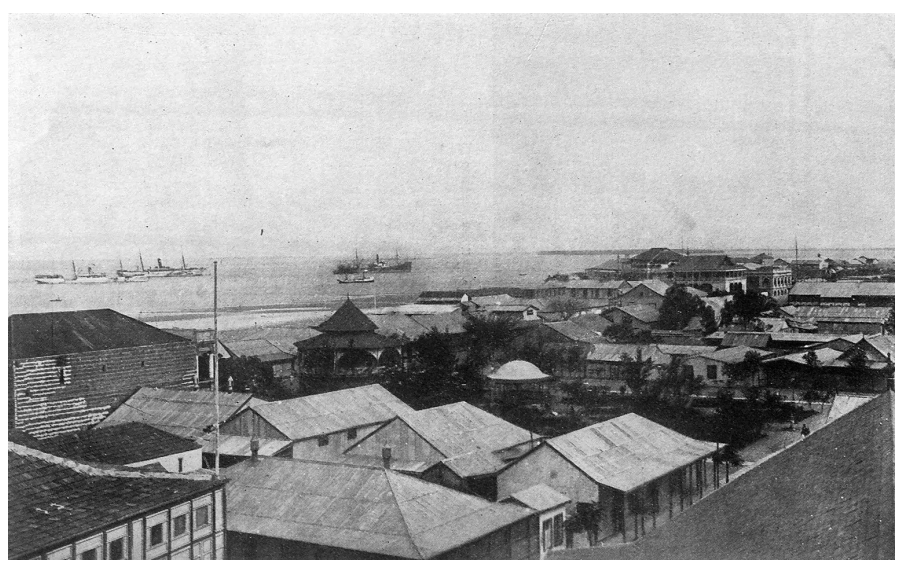

FОTо 8

A Beira em 1905.

Fonte:

Companhia (1934, p. 18).

Igualmente indiscutível é o crescimento do entreposto da Beira, que, de uma zona pantanosa se transformou numa pequena cidade, como se pode ver nas quatro imagens anteriores (fotos 5 a 8 ).

Também o hinterland da Beira beneficiou da via-férrea e do porto (sobretudo a partir dos primeiros anos do século xx), se acreditarmos nos dados sobre concessões de terras, que se concentravam sobretudo ao longo da linha. Além disto, no virar do século, começou-se a registar uma maior importância da cobrança de impostos às populações locais (Direito, 2013, pp. 130, 145, 194-195 e 200).

Este crescimento deveu-se em grande medida à iniciativa estrangeira, contribuindo para a tão temida desnacionalização do território. Em muitos serviços (incluindo porto e ferrovia), empregavam-se a língua inglesa e o sistema de medidas imperial (Direito, 2013, pp. 124, 133 e 147; Navarro, 2018, pp. 399-401). Lawley, um dos empreiteiros da linha, viria a ser cognominado de rei da Beira, dada a sua influência na localidade (Croxton, 1982, p. 41). As estatísticas da cdM são igualmente loquazes a este respeito. O grosso do comércio entrado e saído pela Beira era feito sobretudo por agentes estrangeiros (Figura 10). Naturalmente, a maioria das embarcações arribadas ao porto nacional ostentavam pavilhão não-português, designadamente, inglês, alemão e francês. Em termos de tonelagem dos navios, essa predominância era ainda mais vincada (Figuras 11 e 12).

Em suma, o caminho de ferro (em conjunção com o porto) contribuiu para o desenvolvimento do comércio com a Rodésia, tendo também concorrido para uma maior ocupação de Manica e Sofala, embora tenha sido a Beira que mais beneficiou com os dois sistemas tecnológicos. Contudo, os principais responsáveis por estes fenómenos foram agentes estrangeiros que se fixaram no território. Por outras palavras, a linha funcionava bem do ponto de vista comercial, mas fomentou a presença estrangeira na região, indesejada pelos colonialistas nacionais. 
FIGURA 10

Discriminação da nacionalidade dos fluxos comerciais na Beira, segundo semestre de 1892-1896 e 1907-1914

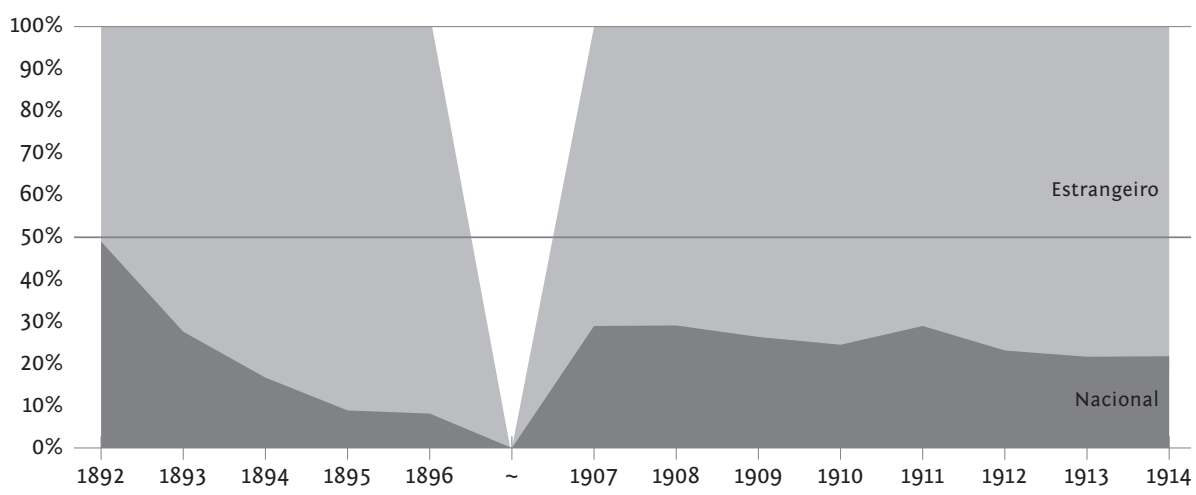

Fonte: Boletim da Companhia de Moçambique (1893-1910); Boletim do Governo do Território da Companhia de Moçambique (1911-1915); Boletins Estatísticos do Movimento Comercial e Marítimo no Território de Manica e Sofala (1908 e 1909); Boletins Estatísticos do Movimento Comercial e Marítimo no Território da Companhia de Moçambique (1910) e Companhia (1902, pp. 334-335).

\section{FIGURA 11}

Discriminação da nacionalidade dos barcos entrados e saídos da Beira, segundo semestre de 1892-1901 e 1907-1910

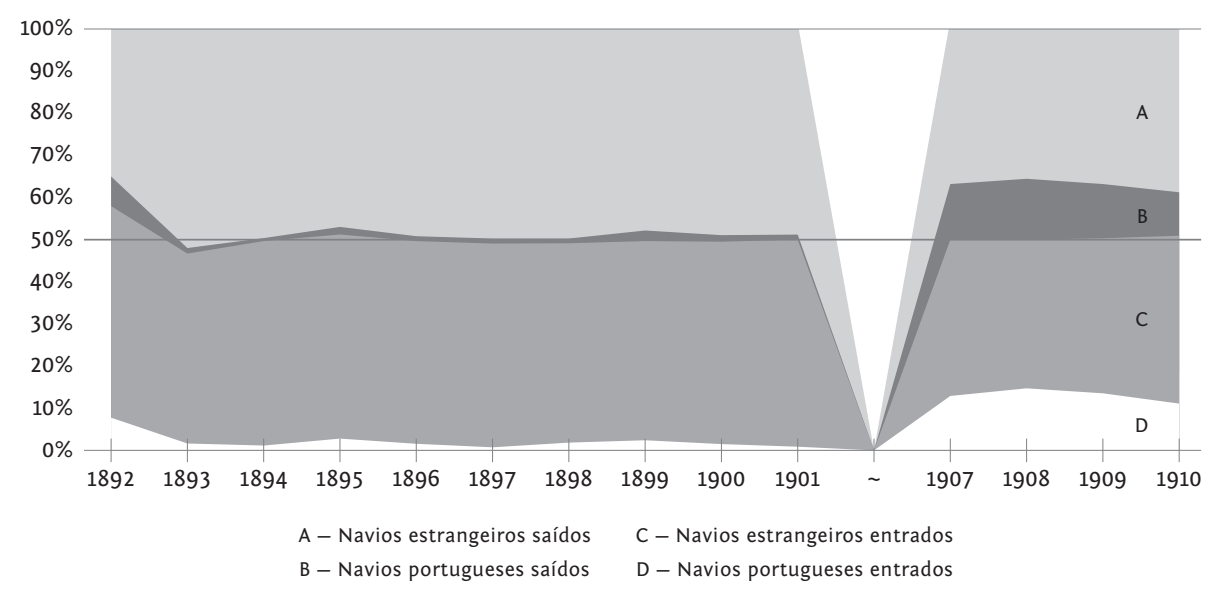

Fonte: Boletim da Companhia de Moçambique (1893-1910); Boletim do Governo do Território da Companhia de Moçambique (1911-1915); Boletins Estatísticos do Movimento Comercial e Marítimo no Território de Manica e Sofala (1908 e 1909); Boletins Estatísticos do Movimento Comercial e Marítimo no Território da Companhia de Moçambique (1910) e Companhia (1902, pp. 334-335). 
FIGURA 12

Discriminação da nacionalidade dos barcos entrados e saídos da Beira (tonelagem), segundo semestre de 1892-1901 e 1907-1910

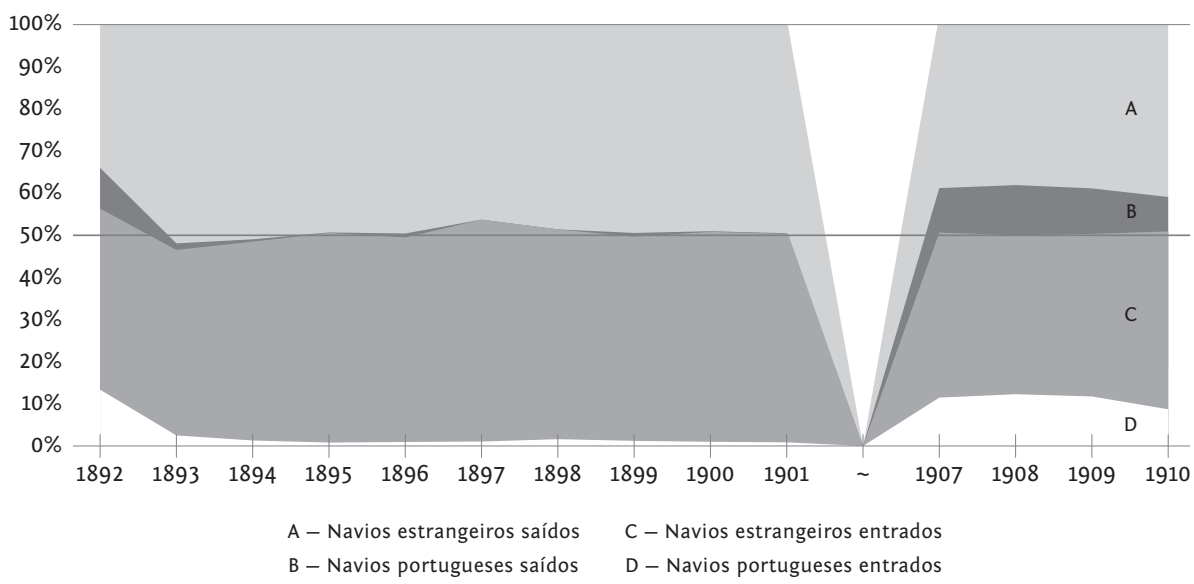

Fonte: Boletim da Companhia de Moçambique (1893-1910); Boletim do Governo do Território da Companhia de Moçambique (1911-1915); Boletins Estatísticos do Movimento Comercial e Marítimo no Território de Manica e Sofala (1908 e 1909); Boletins Estatísticos do Movimento Comercial e Marítimo no Território da Companhia de Moçambique (1910) e Companhia (1902, pp. 334-335).

\section{CONCLUSÃO}

A comunidade nacional de historiadores de tecnologia tem, nos últimos anos, revelado a importância de grandes sistemas tecnológicos e dos seus agentes na estratégia colonial portuguesa. Mais do que um instrumento de especulação comercial e expansão económica, a tecnologia representava o progresso, a domesticação da natureza, a superioridade nacional e a missão civilizadora/ europeizadora de Portugal em África. Daí que à tecnologia, e ao caminho de ferro em particular, fosse também atribuída uma grande importância política e (tecno)diplomática, que exigia uma forte intervenção e atenção do Estado (Pereira, 2017a, pp. 231-234 e 238-250; Diogo, 2009, pp. 473 e 478-479; Diogo e Laak, 2016; Navarro, 2018, pp. 565-572).

Neste sentido, a linha da Beira foge a este modelo, na medida em que foi construída por interesses ingleses, visando a agenda britânica, praticamente sem qualquer intervenção do Estado português. Isto não quer dizer que entre os africanistas nacionais não houvesse vozes que protestavam contra este estado de coisas. Aires de Ornelas (1896, p. 264), futuro governador de Moçambique e ministro da Marinha, é um bom exemplo, quando apelidou a linha da Beira de via dolorosa, tal era a influência inglesa no empreendimento, considerando 
ainda ser "difficil tornar de facto portugueza uma região que hoje apenas o é no nome". A ação da $\mathrm{CdM}$ a este respeito foi a mais audível, em várias cartas nas quais pedia a intervenção do governo metropolitano contra as atitudes das companhias britânicas. Perante a inação do executivo metropolitano, um dos governadores da companhia, Carlos Roma du Bocage (1900), chegou mesmo a acusá-lo de conivência e de querer intencionalmente manter o status quo.

Obviamente, a posição governamental não foi propositada, antes resultou de um conjunto de motivos imperiosos, que aliás o próprio Bocage reconhecia. Portugal debatia-se na altura com disputas internacionais com Inglaterra relativas a outras linhas coloniais. Em relação a Ambaca e Mormugão, o diferendo era com companhias e investidores ingleses, mas sobre Lourenço Marques a disputa fazia-se ao mais alto nível diplomático. Na metrópole, o tesouro procurava reaver o crédito perdido com a bancarrota e com o escândalo da Companhia Real e aceder novamente aos fundos do mercado financeiro de Londres. Criar um novo foco de conflito com Inglaterra na Beira só pioraria a posição internacional de Portugal. A questão da linha tornou-se assim um ninho de vespas. Só se tornaria um problema se fosse perturbado.

Por outro lado, o caminho de ferro foi construído sem qualquer custo para o Estado e funcionava sem necessidade de apoios públicos (bem ao contrário do que acontecia com a maior parte das linhas metropolitanas e coloniais). As estatísticas disponíveis não permitem calcular com certeza o lucro líquido da operação ferroviária (lucro operacional deduzido dos encargos financeiros). Em todo o caso, este não era um problema para o tesouro nacional. A linha funcionava e adicionalmente constituía uma demonstração da capacidade portuguesa para ocupar e colonizar a região. Joaquim Machado foi particularmente eloquente a este respeito. Embora reconhecesse o perigo de desnacionalização do território, afirmava que Portugal não podia "pôr entraves ao que no fundo está facilitando o commercio e a civilisação de Africa, fugindo e com razão á triste reputação que temos adquirido de não fazer nem deixar fazer". ${ }^{47}$ De facto, os números da operação atestam que a linha beneficiou o trânsito da Rodésia, tendo também contribuído para a ocupação efetiva do território da CdM.

Nos primeiros anos do século $\mathrm{xx}$, quando aqueles problemas foram afas$\operatorname{tados}^{48}$, Portugal pôde assumir uma posição negocial mais forte no que tocava

47 CORRESPONDÊNCIA, 1895, 176 (em itálico no original).

48 Em 1900, Portugal pagou uma indemnização aos investidores da linha de Lourenço Marques, tomando-a em pleno direito (Telo, 1991, pp. 163-166). Em 1902, arrendou o caminho de ferro de Mormugão a uma operadora da Índia Britânica, que desbloqueou o tráfego em direção ao porto português (Pereira, 2015, pp. 260-261). Em Ambaca, a questão só $\rightarrow$ 
em particular às tarifas praticadas na linha. Mesmo assim, a margem de manobra era limitada, uma vez que o governo não podia pôr em causa a operação through-traffic assegurada pela MashonalandCo. Tanto na metrópole como no ultramar, as autoridades nacionais já se tinham apercebido da importância de acordos transnacionais para transporte ferroviário cross-borders, pelo que não podia perigar aquele que vigorava em Moçambique. Daí que a pressão sobre as tarifas não tenha sido exagerada, mas tenha resultado num acordo um pouco mais favorável à Beira. De qualquer modo, acabariam por ser forças puramente económicas (o desenvolvimento da Rodésia para além da capacidade de transporte das rotas ferroviárias para a África do Sul e o crescimento de produções agrícolas em Manica e Sofala) que inclinariam o tráfego em direção à linha nacional.

Adicionalmente, a situação agradava também aos interesses ingleses concentrados na BSAC, que assegurava uma segunda saída para o mar, além dos portos sul-africanos. Para a agenda imperialista britânica, a linha tornou-se um instrumento de imperialismo de satélite económico (Divall, 2003, pp. 201-205). O caminho de ferro contribuiu para integrar Manica e Sofala numa economia internacional e para ocupar efetivamente as duas regiões, se bem que na dependência de investidores ingleses. Em conclusão, a linha da Beira, nascida e forjada num ambiente de tensão tecnodiplomática, conseguiu quebrar o obstáculo da fronteira, acabando por servir os interesses económicos das partes envolvidas. a concessionária pagava o juro das obrigações, afastando qualquer possibilidade de os obrigacionistas britânicos confiscarem a infraestrutura (Navarro, 2018, pp. 312-314). 


\title{
REFERÊNCIAS BIBLIOGRÁFICAS
}

\author{
SIGLAS E ACRÓNIMOS
}

$\begin{array}{ll}\text { AHU } & \text { Arquivo Histórico Ultramarino. } \\ \text { BeiraCo } & \text { Beira Railway Company. } \\ \text { BSAC } & \text { British South Africa Company. } \\ \text { CdM } & \text { Companhia de Moçambique. } \\ \text { COLP } & \text { Collecção Official de Legislação Portugueza. } \\ \text { CORRESPONDÊNCIA } & \text { Copia de documentos officiaes trocados entre a Companhia de Moçambi- } \\ & \text { que e o Governo de Sua Magestade, Lisboa, Imprensa Nacional. } \\ \text { DCD } & \text { Diario da Camara dos Deputados. } \\ \text { DRO } & \text { Derbyshire Record Office. } \\ \text { JunctionCo } & \text { Beira Junction Railway Company. } \\ \text { L\&P } & \text { London \& Paris Exploitation Company. } \\ \text { LEGIS } & \text { Legislação e disposições regulamentares sobre caminhos de ferro } \\ & \text { ultramarinos, Lisboa, Imprensa Nacional. } \\ \text { MashonalandCo } & \text { Mashonaland Railway Company. } \\ \text { RhodesiaCo } & \text { Rhodesia Railway Company. } \\ \text { RG } & \text { The Railway Gazette. } \\ \text { RT } & \text { The Railway Times. } \\ \text { TNA } & \text { The National Archives. }\end{array}$

FONTES

ALFord, C.J. (1893), "De Durban à Beira”. Boletim da Sociedade de Geografia de Lisboa, 2, pp. 105-120.

Bocage, C.R. du (1900), Exposição ácerca das Negociações Relativas ao Caminho de Ferro da Beira, Lisboa, Companhia Nacional.

companhia de Moçambique (1902), O Territorio de Manica e Sofala e a Administração da Companhia de Moçambique (1892-1900), Lisboa, Companhia Nacional.

companhia de Moçambique (1934), Quarenta Anos de Administração no Territorio de Manica e Sofala. Documentario fotografico Apresentado na Primeira Exposição Colonial Portuguesa, Lisboa, Sociedade Nacional de Tipografia.

MaChado, J. J. (1895), "O Territorio de Manica e Sofala sob a administração da Companhia de Moçambique”. Boletim da Sociedade de Geographia de Lisboa, 6, pp. 491-533.

mourA, F. I. G. (1885), "De Villa Gouveia no Gorongoza ao rio Pungué". Boletim da Sociedade de Geografia de Lisboa, 8, pp. 492-496.

ORNELAS, A. de (1896), "O caminho de ferro da Beira e a passagem das tropas imperiaes inglezas em Julho de 1896". Revista do Exército e da Armada, 7, pp. 257-264.

Pauling, G. (1969), The Chronicles of a Contractor. Being the Autobiography of the Late George Pauling, Bulawayo, Books of Rhodesia.

PERY, G. A. (1875), Geographia e Estatistica Geral de Portugal e Colonias, Lisboa, IN. vilhena, J. de (1916), Antes da Republica (notas autobiográficas), Coimbra, França \& Arménio. 
Alexandre, V. (2008), A Questão Colonial no Parlamento 1821-1910, Lisboa, D. Quixote. Alexandre, V., DiAs, J. (coords.) (1998), “O império africano 1825-189o". In J. Serrão, A. H. Oliveira Marques (dirs.), Nova História da Expansão Portuguesa, Lisboa, Estampa, vol. x. amaral, I. (1969), "Beira, cidade e porto do Índico". Finisterra. Revista Portuguesa de Geografia, 4(7), pp. 77-93.

AXeLson, E. (1967), Portugal and the Scramble for Africa, Joanesburgo, Witwatersrand University Press.

Baxter, A. (1998), The Two Foot Gauge Enigma. Beira Railway, 1890-1900, Norwich, Plateway. BOUENE, F., SANTOS, M. (2006), “O modus vivendi entre Moçambique e o Transvaal (1901-1909). Um caso de 'imperialismo ferroviário”'. Africana Studia, 9, pp. 239-269.

Croxton, A. (1982), Railways of Zimbabwe. The Story of the Beira, Mashonaland and Rhodesia Railways, Londres, David \& Charles.

DIOGO, M.P. (2009), “Domesticating' the wilderness: Portuguese engineering and the occupation of Africa”. In A. Cardoso de Matos et al. (eds.), The Quest for a Professional Identity: Engineers Between Training and Action, Lisboa, Colibri, pp. 471-483.

DIOGO, M.P., LAAK, D. van (2016), Europeans Globalizing: Mapping, Exploiting, Exchanging, Londres, Palgrave-MacMillan.

Direito, B. P. T. (2013), Políticas Coloniais de Terras em Moçambique: o caso de Manica e Sofala sob a Companhia de Moçambique. Tese de doutoramento, Lisboa, Universidade de Lisboa. DIVALL, C. (2003), "Railway imperialisms, railway nationalisms”. In M. Burri, K. T. Elsasser, D. Gugerli (eds.), Die Internationalität der Eisenbahn 1850-1970, Zurique, Chronos, pp. 195-209 .

FAYE, M.L., et al. (2004), "The challenges facing landlocked developing countries". Journal of Human Development, 5(1), pp. 31-68.

fernandes, P. J. (2010), Mariano Cirilo de Carvalho: o "Poder Oculto" do Liberalismo Progressista (1876-1892), Lisboa, Texto.

GaO, J.Z. (1997), Meeting Technology's Advance. Social Change in China and Zimbabwe in the Railway Age, Londres, Greenwood.

HANES III, W. T. (1991), "Railway politics and imperialism in Central Africa, 1889-1953". In C. B. Davis, K.E. Wilburn Jr, R.E. Robinson (eds.), Railway Imperialism, Londres, Greenwood, pp. 41-69.

Lima, A.P. de (1971), História dos Caminhos de Ferro de Moçambique, Lourenço Marques, Administração dos Portos, Caminhos de Ferro e Transportes de Moçambique.

LÓPEZ, E. et al. (2009), "Assessment of cross-border spillover effects of national transport infrastructure plans: an accessibility approach". Transport Reviews, 29(4), pp. 515-536.

LunN, J. (1997), Capital and Labour on the Rhodesian Railway System, 1888-1947, Londres, MacMillan.

mata, M. E. (1993), As Finanças Públicas Portuguesas da Regeneração à Primeira Guerra Mundial, Lisboa, Banco de Portugal.

MUN, S., NAKagaWa, S. (2010), "Pricing and investment of cross-border transport infrastructure". Regional Science and Urban Economics, 40(4), pp. 228-240.

navarro, B. J. (2018), Um Império Projectado pelo "Silvo da Locomotiva". O Papel da Engenharia Portuguesa na Apropriação do Espaço Colonial Africano. Angola e Moçambique (1869-1930), Lisboa, Colibri.

Newitt, M. (1981), Portugal in Africa. The Last Hundred Years, Londres, Hurst.

NYE, D. E. (1999), American Technological Sublime, Cambridge, Miт Press. 
pakenham, T. (2003), The Scramble for Africa. White Man's Conquest of the Dark Continent From 1876 to 1912, Nova Iorque, Perennial.

pereira, H.S. (2012), A Política Ferroviária Nacional (1845-1899). Tese de doutoramento, Porto, Universidade do Porto.

Pereira, H.S. (2015), "Fontismo na Índia Portuguesa: o caminho-de-ferro de Mormugão". Revista Portuguesa de História, 46, pp. 237-262.

PEREIRA, H.S. (2017a), "Fronteiras e caminhos-de-ferro: da quimera saint-simoniana ao desencanto tecnodiplomático (c. 1850-c. 1900)”. Revista de História das Ideias, 35, pp. 227-259.

PEREIRA, H.S. (2017b), "The technodiplomacy of Iberian transnational railways in the second half of the nineteenth century". History and Technology, 33(2), pp. 175-195.

Pinheiro, M. (1995), "L'histoire d'un divorce: l'Intégration des chemins de fer Portugais dans le réseau Ibérique”. In M. Merger, A. Carreras, A. Giuntini (eds.), Les réseaux européens transnationaux XIXe-Xxe siècles: quels enjeux?, Nantes, Ouest Éditions, pp. 335-349.

puffert, D. J. (2009), Tracks Across Continents, Paths Through History. The Economic Dynamics of Standardization in Railway Gauge, Chicago, University of Chicago Press.

Robinson, R.E. (1991), “Conclusion: railways and informal empire”. In C. B. Davis, K. E. Wilburn Jr, R. E. Robinson (eds.), Railway Imperialism, Londres, Greenwood, pp. 175-197.

SANTOS, L.A. (2001), "A crise financeira de 1891: uma tentativa de explicação". Análise Social, 36(158-159), pp. 185-207.

SUnderland, D. (2012). Communications in Africa, 1880-1939, Londres, Routledge.

TeIXeIra, M.L.N.P. (1991), The Railways of Mozambique - A Regional or Colonial Project? 1895-1950. Tese de mestrado, Montreal, Concordia University.

Telo, A. J. (1991), Lourenço Marques na Política Externa Portuguesa, Lisboa, Cosmos.

vasconcelos, E. J.C. (1921), As Colónias Portuguesas. Geografia Física, Económica e Política, Lisboa, Clássica.

VIDAL, J. (1995), “Marchés nationaux ou internationaux? Les compagnies de chemins de fer en Espagne et leurs connexions internationales avec la France et le Portugal, 1850-1914." In M. Merger et al., op. cit., Nantes, Ouest Éditions, pp. 350-365.

Vleuten, E. van der, KAIJSER, A. (2006), “Transnational networks and the shaping of contemporary Europe”. In E. van der Vleuten, A. Kaijser (eds.), Networking Europe. Transnational Infrastructures and the Shaping of Europe, 1850-2000, Sagamore Beach, Science History Publications, pp. 1-22.

vleuten, E. van der (2006), "Understanding network societies. Two decades of large technical system studies”. In E. van der Vleuten, A. Kaijser (eds.), Networking Europe. Transnational Infrastructures and the Shaping of Europe, 1850-2000, Sagamore Beach, Science History Publications, pp. 279-314.

Recebido a 04-04-2018. Aceite para publicação a 08-03-2019.

PEReIra, H. S. (2019), "O caminho de ferro da Beira em Moçambique (1890-1914): entre antagonismo tecnodiplomático e simbiose económica”. Análise Social, 233, LIV (4. ${ }^{\circ}$ ), pp. 694-724.

Hugo Silveira Pereira » hugojose.pereira@gmail.com » Centro Interuniversitário de História das Ciências e da Tecnologia, Faculdade de Ciências e Tecnologia, Universidade Nova de Lisboa e Institute of Railway Studies, University of York » Campus de Caparica, Edif. viI, Piso 2 - 2829-516 Caparica, Portugal » https:// orcid.org/00oo-0002-7706-2686. 